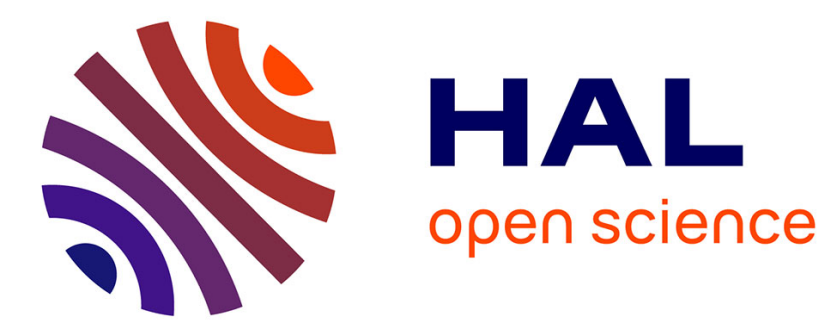

\title{
Rhenium-osmium isotope systematics in MORB from the Southern Mid-Atlantic Ridge (40-50 S)
}

\author{
Stéphane Escrig, Pierre Schiano, Jean-Guy Schilling, Claude Allègre
}

\section{To cite this version:}

Stéphane Escrig, Pierre Schiano, Jean-Guy Schilling, Claude Allègre. Rhenium-osmium isotope systematics in MORB from the Southern Mid-Atlantic Ridge (40-50 S). Earth and Planetary Science Letters, 2005, 235, pp.528-548. 10.1016/j.epsl.2005.04.035 . hal-00468943

\section{HAL Id: hal-00468943 \\ https://hal.science/hal-00468943}

Submitted on 18 Nov 2021

HAL is a multi-disciplinary open access archive for the deposit and dissemination of scientific research documents, whether they are published or not. The documents may come from teaching and research institutions in France or abroad, or from public or private research centers.
L'archive ouverte pluridisciplinaire HAL, est destinée au dépôt et à la diffusion de documents scientifiques de niveau recherche, publiés ou non, émanant des établissements d'enseignement et de recherche français ou étrangers, des laboratoires publics ou privés.

\section{(ㅇ)(1) $\$$}

Distributed under a Creative Commons Attribution - NonCommerciall 4.0 International 


\title{
Rhenium-osmium isotope systematics in MORB from the Southern Mid-Atlantic Ridge $\left(40^{\circ}-50^{\circ} \mathrm{S}\right)$
}

\author{
Stéphane Escrig ${ }^{\mathrm{a}, *}$, Pierre Schiano ${ }^{\mathrm{a}, \mathrm{b}}$, Jean-Guy Schilling ${ }^{\mathrm{c}}$, Claude Allègre ${ }^{\mathrm{a}}$ \\ ${ }^{a}$ Laboratoire de Géochimie et Cosmochimie (UMR 7579 CNRS), Institut de Physique du Globe de Paris, Université Denis Diderot (Paris 7), \\ 4 place Jussieu, 75252 Paris Cedex 05, France \\ baboratoire 'Magma et Volcans', Université Blaise-Pascal, CNRS (UMR 6524), Observatoire de Physique du Globe de Clermont-Ferrand, \\ 5 rue Kessler, 63038 Clermont-Ferrand Cedex, France \\ ${ }^{\mathrm{c}}$ Graduate School of Oceanography, University of Rhode Island, Kingston, Rhode Island 02881, USA
}

\begin{abstract}
We present 27 osmium isotopic analyses and Re-Os contents in MORB glasses from the South Atlantic ridge $\left(40^{\circ}-50^{\circ} \mathrm{S}\right)$, an area showing an important mantle source heterogeneity expressed by large variations in trace element and $\mathrm{Sr}, \mathrm{Nd}$ and $\mathrm{Pb}$ isotope compositions. Os concentrations are very low and range from 1.37 to $12.47 \mathrm{ppt}$ and Re concentrations range from to 0.44 to $2.13 \mathrm{ppb}$. The ${ }^{187} \mathrm{Os} /{ }^{188} \mathrm{Os}$ ratios vary from 0.1314 to 0.2316 and define a global positive correlation with $1 / \mathrm{Os}$. A multidimensional analysis of our dataset reveals that ${ }^{187} \mathrm{Os} /{ }^{188} \mathrm{Os}$ ratio is independent from the other isotopic systems or that it provides complementary information on the nature of the processes affecting the upper mantle. Using trace element and $\mathrm{Sr}$ isotopic ratios to distinguish the different processes affecting the South Atlantic MORB source, our results enable an assessment of their effects on the Os isotopic composition. The variable ${ }^{187} \mathrm{Os} /{ }^{188} \mathrm{Os}$ ratios of N-MORB samples could be attributed to metasomatism of the asthenospheric mantle by melt percolation related to an ancient subducting zone. The ${ }^{187} \mathrm{Os} /{ }^{188} \mathrm{Os}$ ratio appears also to be very sensitive to plume-ridge interaction and its latitudinal variation along the $47.35^{\circ}-48.5^{\circ} \mathrm{S}$ segment confirms the migration of material from the Discovery plume southward the Agulhas FZ. Finally, associated to $\mathrm{Pb}-\mathrm{Sr}-\mathrm{Nd}$ isotopic ratios, the ${ }^{187} \mathrm{Os} /{ }^{188} \mathrm{Os}$ ratios measured in E-MORB from the $48.5^{\circ}-49.2^{\circ} \mathrm{S}$ segment confirm that delaminated lower continental crust is responsible for the DUPAL signature observed in the South Atlantic and Indian Oceans.
\end{abstract}

Keywords: mid-ocean ridge basalts; MORB; osmium; upper mantle; mantle heterogeneity; DUPAL anomaly

* Corresponding author. Department of Earth and Planetary Sciences, Harvard University, 20 Oxford Street, Cambridge, MA 02138, USA. Tel.: +1 617496 6983; fax: +1 6174966958 . E-mail address: escrig@eps.harvard.edu (S. Escrig).

\section{Introduction}

The large isotopic dataset available for Mid-Ocean Ridge Basalts (MORB), which are produced by melt- 
ing of the convecting depleted upper mantle, has revealed important $\mathrm{Pb}, \mathrm{Sr}, \mathrm{Nd}$ isotopic variations (e.g., [1-5]) which have been attributed to various processes. On a small geographical scale, isotopic variations along the ridge are generally associated to the entrainment of upwelling materials derived from nearby plumes (e.g. [6]), with the possible influence of fracture zone on the magma flow $[7,8]$. On a larger scale, the origin of the DUPAL isotopic anomaly (characterized by higher ${ }^{87} \mathrm{Sr} /{ }^{86} \mathrm{Sr}$ and lower ${ }^{206} \mathrm{~Pb} /{ }^{204} \mathrm{~Pb}$ on average than Pacific MORB) observed in MORB from the Indian Ocean and the southern Atlantic Ocean $[9,10]$ has been attributed to contamination by subduction-related materials $[11,12]$, the presence in the MORB source of subcontinental lithosphere fragments $[13,14]$ or delaminated lower continental crust [15]. Finally, it has been proposed that there is a global isotopic heterogeneity in the upper mantle, in which variations toward high ${ }^{206} \mathrm{~Pb} /{ }^{204} \mathrm{~Pb}$ and low ${ }^{87} \mathrm{Sr} /{ }^{86} \mathrm{Sr}$ ratios in normal MORB (N-MORB) reflect the presence of stretched strips of recycled oceanic lithosphere in the upper mantle peridotites through a marble-cake structure [16].

The difference in the behavior of $\mathrm{Re}$ and Os during melting processes provides a new tool to study the nature of mantle heterogeneities. Since Re behaves as a moderately incompatible element and $\mathrm{Os}$ as a strongly compatible, melt-derived products have high $\mathrm{Re} / \mathrm{Os}$ and rapidly develop radiogenic ${ }^{187} \mathrm{Os} /{ }^{188} \mathrm{Os}$ by $\beta^{-}$decay of ${ }^{187} \mathrm{Re}$ to ${ }^{187} \mathrm{Os}\left(\lambda=1.666 \times 10-11 \mathrm{yr}^{-1} \quad[17]\right)$. Radiogenic ${ }^{187} \mathrm{Os} /{ }^{188} \mathrm{Os}$ signature is thus a potential tracer for recycled crustal materials in the Earth's mantle. Accordingly, the radiogenic ${ }^{187} \mathrm{Os} /{ }^{188} \mathrm{Os}$ ratios of some oceanic basalts indicate the presence of recycled oceanic crust component in plume sources [18-22].

Previous measurements of N-MORB glasses sampled in mid-ocean-ridge regions unaffected by the vicinity of hotspots $[15,23-25]$ have revealed a very large range of Os isotopic compositions and significantly higher ${ }^{187} \mathrm{Os} /{ }^{188} \mathrm{Os}$ ratios than the abyssal peridotites $[23,26-29]$ and the primitive upper mantle value [30] (see Fig. 1). Such radiogenic compositions are interpreted either as the result of seawater contamination [31], as the effect of in-situ decay of ${ }^{187} \mathrm{Re}$ $[25,32]$, or as the primary features reflecting mantle chemical heterogeneities $[15,24]$. Recent Os studies of

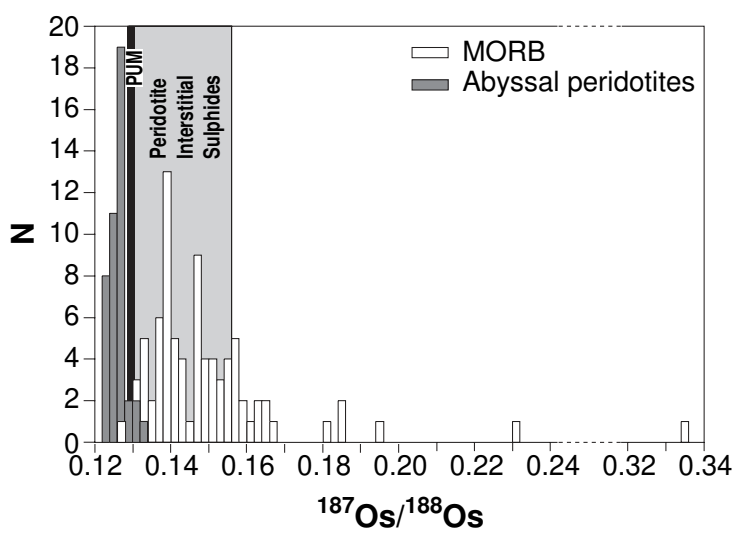

Fig. 1. Histogram of Os isotopic compositions of mid-oceanic ridge basalt (this study and data from Schiano et al. [24], Gannoun et al. [25], and Escrig et al. [15]) and abyssal peridotites [23,26-29]. The estimate of the primitive upper mantle value (PUM) [30] is shown as a black bar and the range of variation of peridotite Ni-rich interstitial sulphides [36] as a grey field.

mantle peridotites have revealed the co-existence of two sulfide populations with very distinct Os isotopic compositions, one constituted by unradiogenic sulphides residual from mantle melting and included in silicate phases, and one constituted by radiogenic interstitial $\mathrm{Cu}-\mathrm{Ni}$-rich sulphides derived from nonextracted mantle partial melts [33-35]. The presence of interstitial radiogenic sulphides in peridotites prior to the melting processes that produce MORB is also a possible explanation for their high ${ }^{187} \mathrm{Os} /{ }^{188} \mathrm{Os}$ ratios [36].

The Southern Mid-Atlantic Ridge (MAR) is well known for exhibiting important trace element and isotopic variability with both normal MORB (N-MORB) and enriched MORB (E-MORB). In particular, MORB from the $40^{\circ}-50^{\circ} \mathrm{S}$ MAR segment display important variations in major elements, trace elements and $\mathrm{Sr}, \mathrm{Nd}, \mathrm{Pb}, \mathrm{Hf}, \mathrm{He}, \mathrm{Ne}$ isotopic ratios which have led to the identification of several components in the local upper mantle [8,37-42]. These components include a predominant asthenospheric mantle, which has been metasomatised through the percolation of sediment-derived melts prior to the Gondwana break-up [41]. Another component corresponds to the off-axis Discovery mantle plume that interacts with the local asthenospheric mantle and provides the enriched contribution for most of the E-MORB [8]. Finally, Douglass et al. [8] have proposed that the presence of an additional component termed LOMU 
(for low $\mu, \equiv{ }^{238} \mathrm{U} /{ }^{204} \mathrm{~Pb}$ ) is responsible for the DUPAL signature of some E-MORB.

\section{Geological setting and geochemical latitudinal segmentation}

The $40^{\circ}-50^{\circ} \mathrm{S}$ ridge segment is located in the South Atlantic Ocean, North of the Bouvet triple junction and South of the Gough hot spot. In this area, the southern segment of the ridge shows an inflated axial topography that reflects a thermal anomaly consistent with the vicinity of the Discovery and Shona mantle plumes. The ridge segment is affected by two main transform offsets, the Agulhas fracture zone (FZ) and the $49^{\circ} \mathrm{S} \mathrm{FZ}$, and, to a lesser extent, by smaller offsets including the $48.5^{\circ} \mathrm{S} \mathrm{FZ}$ and the $50^{\circ} \mathrm{S}$ FZ (Fig. 2). Previous MORB studies have revealed that trace element ratios $[38,41]$ as well as isotopic ratios $[8,40,42]$ show important variations along the $40^{\circ}-50^{\circ} \mathrm{S}$ segment of the Atlantic ridge. This segment can be divided into several latitudinal sub-segments showing distinct isotopic signatures that are often separated by physical discontinuities (Fig. 3). As illustrated in Fig. 3, the studied area can be divided into five segments (labeled S1 to S5) that include two segments ( $\mathrm{S} 1$ and $\mathrm{S} 5$ ) displaying $\mathrm{N}-\mathrm{MORB}$ trace element composition (e.g., $(\mathrm{La} / \mathrm{Sm})_{n}<1$ and $\mathrm{Zr}$ / $\mathrm{Nb}>30$ ) together with variable $\mathrm{Sr}, \mathrm{Nd}, \mathrm{Pb}$ isotopic ratios, one segment (S2) with $\mathrm{N}$-and E-MORB trace element compositions and two segments (S3 and S4) showing only or chiefly enriched trace element and isotopic compositions likely to reflect the contribution of material from the Discovery mantle plume and/or a LOMU component [8]. In terms of major element composition, the N-MORB segments (S1 and S5) display significantly higher $\mathrm{MgO}$ and lower $\mathrm{SiO}_{2}$ and $\mathrm{TiO}_{2}$ contents than the E-MORB segments (S2-S4). In addition, since Klein and Langmuir [43] have shown that the $\mathrm{Na}_{8}$ content of MORB $\left(\mathrm{Na}_{2} \mathrm{O}\right.$ content corrected to a constant $\mathrm{MgO}$ content of 8 wt. \% by removing the effects of low pressure fractionation) is principally controlled by the temperature of melting, the regular increase of $\mathrm{Na}_{8}$ of N-MORB (S1 and S5) samples toward the Discovery anomaly is consistent with a radial thermal effect of the Discovery plume on the MORB mantle source. In order to grasp the distinct geochemical areas, the most notable features of each segment are developed below.

$\mathrm{N}-\mathrm{MORB}$, northern region $\left(40^{\circ}-45^{\circ} \mathrm{S}\right.$, labeled S1): Despite N-MORB-like trace element compositions, samples from this ridge segment have variable

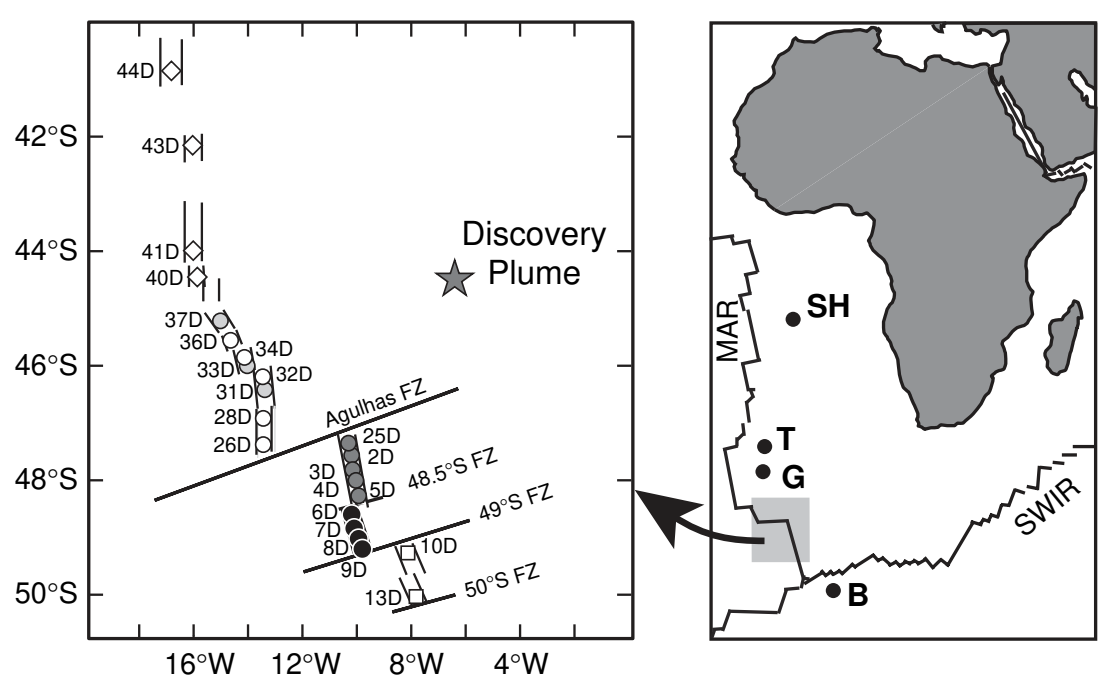

Fig. 2. Schematic map of the $40^{\circ}-50^{\circ} \mathrm{S}$ segment of the South Atlantic ridge, showing the location of dredge stations, the corresponding dredge number and the present-day location of the off-axis Discovery mantle plume. Circles correspond to segments where the influence of Discovery mantle plume has been identified [8,41]. White symbols (diamonds, circles and squares) correspond to samples with $(\mathrm{La} / \mathrm{Sm})_{N}<0.9$ and/or ${ }^{87} \mathrm{Sr} /{ }^{86} \mathrm{Sr}<0.7035$. 


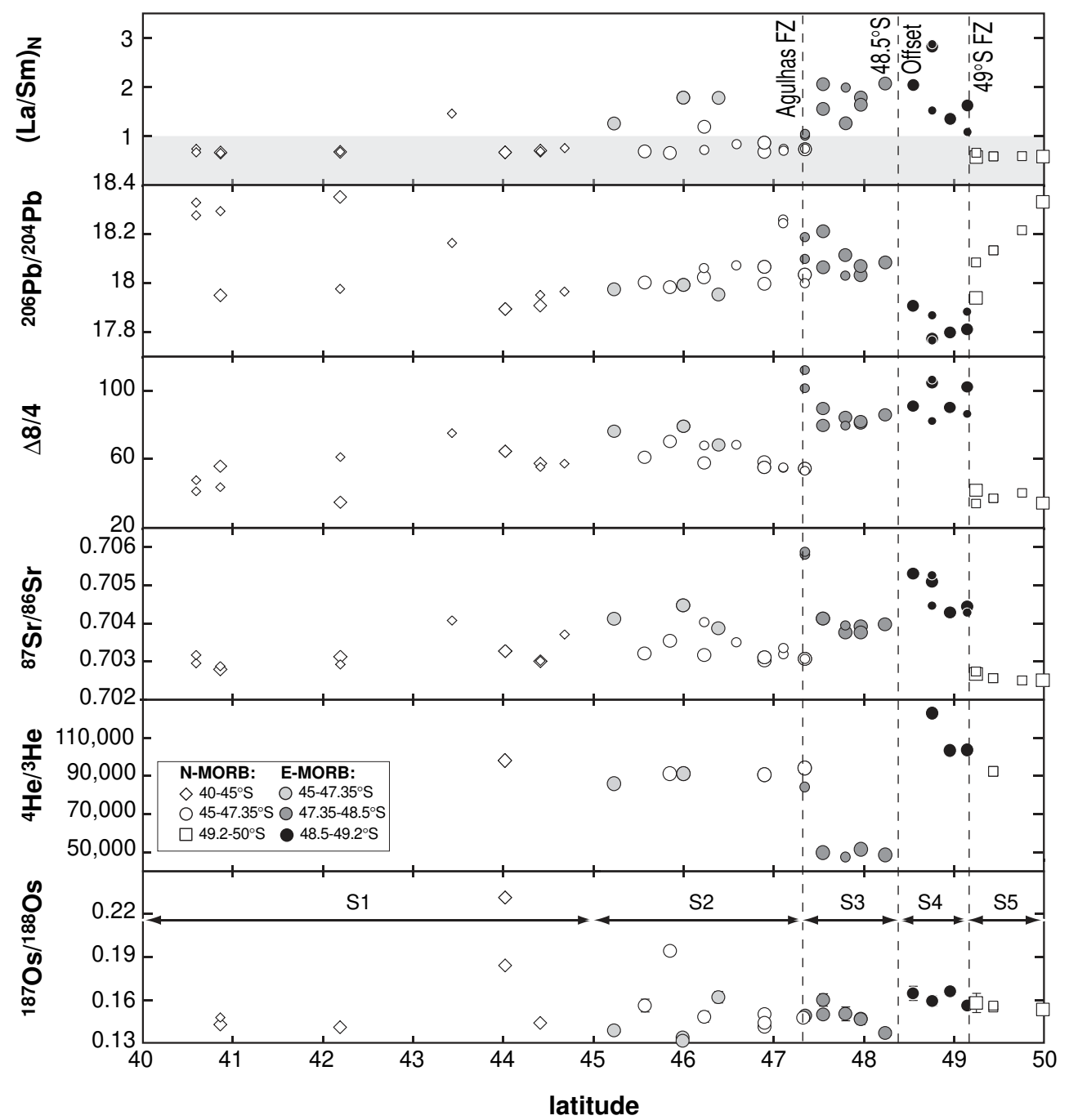

Fig. 3. Latitudinal variation of $(\mathrm{La} / \mathrm{Sm})_{N},{ }^{206} \mathrm{~Pb} /{ }^{204} \mathrm{~Pb}, \Delta 8 / 4,{ }^{4} \mathrm{He} /{ }^{3} \mathrm{He},{ }^{87} \mathrm{Sr} /{ }^{86} \mathrm{Sr}$ and ${ }^{187} \mathrm{Os} /{ }^{188} \mathrm{Os}$. $(\mathrm{La} / \mathrm{Sm})_{N}$ and $\mathrm{Pb}$ and $\mathrm{Sr}$ isotopic ratios are from $[8,38] .{ }^{4} \mathrm{He} /{ }^{3} \mathrm{He}$ ratios are from [40]. Dashed lines represent the location of important fracture zones and offsets that separate ridge segments with distinct compositions. Symbols: white diamonds $=40^{\circ}-45^{\circ} \mathrm{S}$ segment, labeled S1; white circles $=$ samples with $(\mathrm{La} / \mathrm{Sm})_{N}<0.9$ and $/$ or ${ }^{87} \mathrm{Sr} /{ }^{86} \mathrm{Sr}<0.7035$ from $45-47.35^{\circ} \mathrm{S}$ segment, labeled S2; grey circles=samples with $(\mathrm{La} / \mathrm{Sm})_{N}>0.9$ from $45^{\circ}-47.35^{\circ} \mathrm{S}$ segment $(\mathrm{S} 2)$; dark grey circles $=47.35^{\circ}-48.5^{\circ} \mathrm{S}$ segment, labeled S3; black circles $=48.5^{\circ}-49.2^{\circ} \mathrm{S}$ segment, labeled S4; white squares $=49.2^{\circ}-50^{\circ} \mathrm{S}$ segment, labeled S4. Small symbols correspond to MORB from $[8,38]$ that have not been analyzed for Os in this study. In the diagram ${ }^{187}$ Os $/{ }^{188}$ Os ratio vs. latitude, small symbols are taken from [24]. The influence of the Discovery mantle plume is limited to the segments represented by circles. White symbols correspond to samples with N-MORB-like composition. The segments have distinctive trace and isotopic ratios that reflect the involvement of several mantle components in the MORB source. N-MORB samples display variable ${ }^{206} \mathrm{~Pb} /{ }^{204} \mathrm{~Pb}, \Delta 8 / 4$ and ${ }^{187} \mathrm{Os} /{ }^{188} \mathrm{Os}$ as well as $\mathrm{Nb}$ anomalies (see [41]) which suggest a contamination event of the local asthenospheric mantle unrelated to the plume-ridge interaction. Basalts influenced by the Discovery Mantle plume have high ${ }^{87} \mathrm{Sr} /{ }^{86} \mathrm{Sr}$ and low ${ }^{206} \mathrm{~Pb} /{ }^{204} \mathrm{~Pb}$ and ${ }^{4} \mathrm{He} /{ }^{3} \mathrm{He}$. Basalts from the $48.5^{\circ}-49.2^{\circ} \mathrm{S}$ segment are influenced by a low $\mu\left(={ }^{238} \mathrm{U} /{ }^{204} \mathrm{~Pb}\right)$ component and have very low ${ }^{206} \mathrm{~Pb} /{ }^{204} \mathrm{~Pb}$ together with high ${ }^{4} \mathrm{He} /{ }^{3} \mathrm{He},{ }^{87} \mathrm{Sr} /{ }^{86} \mathrm{Sr}, \Delta 8 / 4$ and ${ }^{187} \mathrm{Os} /{ }^{188} \mathrm{Os}$.

$\mathrm{Pb}, \mathrm{Sr}, \mathrm{Nd}$ isotopic ratios, which are interpreted to reflect metasomatism of the local asthenospheric depleted upper mantle by sediment-derived melts [41].
Northern Discovery Segment $\left(45^{\circ}-47.35^{\circ} \mathrm{S}\right.$, labeled S2): This area corresponds to the northern segment of the Discovery Ridge Anomaly. It is 
characterized by a large range of trace element ratios and appears therefore as a transitional segment with increasing influence of at least one enriched component in the MORB source. Overall, there is no correlation between trace element ratios and $\mathrm{Pb}-\mathrm{Sr}-\mathrm{Nd}$ isotopic ratios in samples from this segment. In a previous study, Douglass et al. [8] have interpreted the isotopic variation observed from this segment as a consequence of the Discovery plume-ridge interaction. However, Fig. 4 shows that the relationships between the $\mathrm{Pb}$,

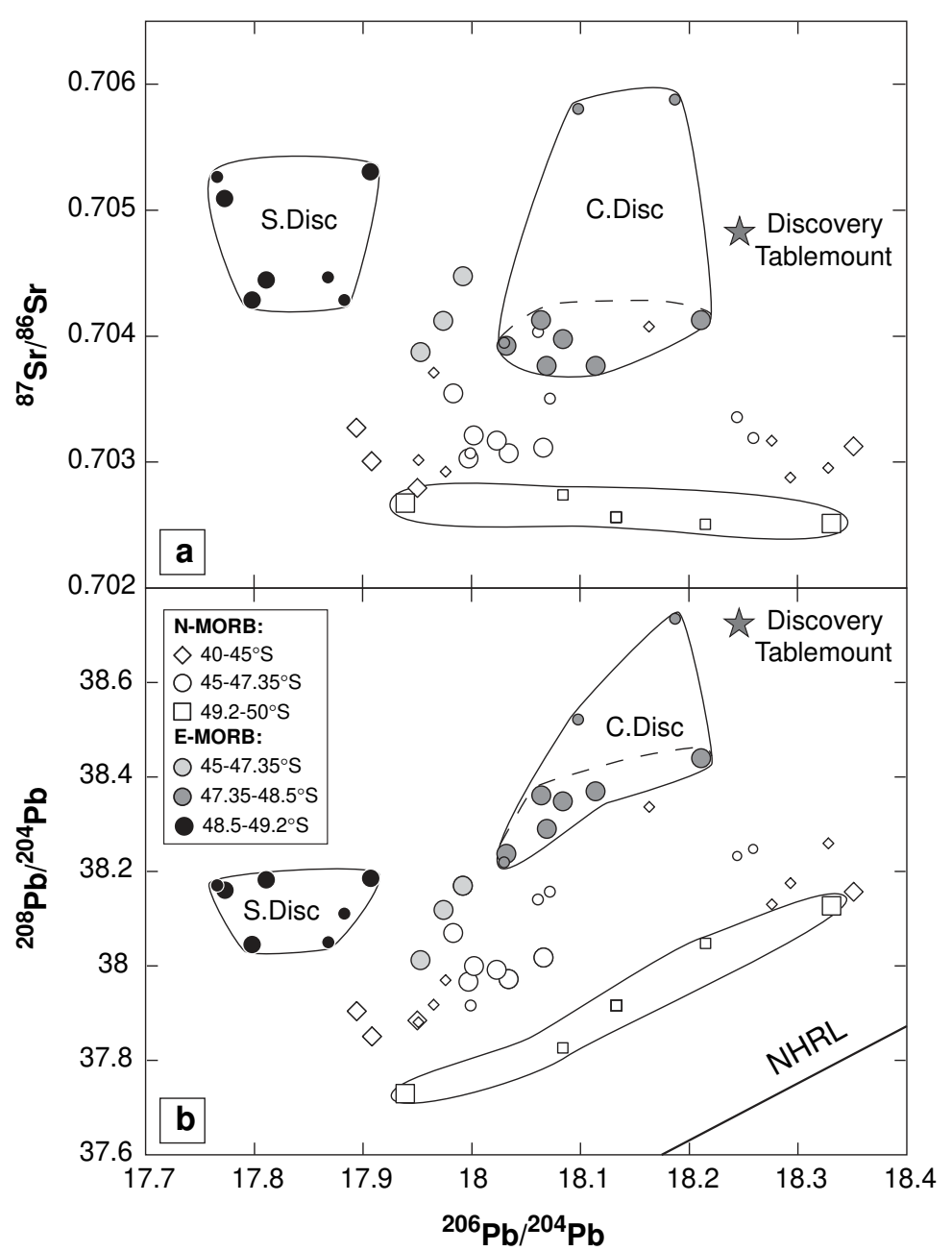

Fig. 4. ${ }^{87} \mathrm{Sr} /{ }^{86} \mathrm{Sr}(\mathrm{a}),{ }^{206} \mathrm{~Pb} /{ }^{204} \mathrm{~Pb}$ (b) vs. ${ }^{208} \mathrm{~Pb} /{ }^{204} \mathrm{~Pb}$ diagrams. Symbols given in the inset correspond to the latitudinal distinction of Fig. 2 , with the exception of segment $45^{\circ}-47.35^{\circ} \mathrm{S}$ where N-MORB samples with $(\mathrm{La} / \mathrm{Sm})_{N}<0.9$ and $/$ or ${ }^{87} \mathrm{Sr} /{ }^{86} \mathrm{Sr}<0.7035$ are represented as white circles and E-MORB samples as grey circles. The non-white symbols correspond to E-MORB samples influenced either by plume material or a 'LOMU' component. The grey star corresponds to the composition of the Discovery tablemount [41]. Also shown is the North Hemisphere Reference Line (NHRL) as defined by [10]. Samples from central segment tend toward the tablemount composition. The dashed line within the Central segment field excludes samples from dredge 25D with MORB-like ${ }^{4} \mathrm{He} /{ }^{3} \mathrm{He}$. Samples with the 'LOMU' component influence define a field distinct from the other MORB analyzed in this study with significantly lower ${ }^{206} \mathrm{~Pb} /{ }^{204} \mathrm{~Pb}$ ratios than the central segment. E-MORB samples from $45^{\circ}-47.35^{\circ} \mathrm{S}$ segment (grey circles) display intermediate positions between N-MORB (white symbols) and E-MORB from Central (dark grey circles) or Southern (black circles) segments. N-MORB from the different segments show important ${ }^{206} \mathrm{~Pb} /{ }^{204} \mathrm{~Pb}$ variations toward radiogenic values for a restricted range of ${ }^{87} \mathrm{Sr} /{ }^{86} \mathrm{Sr}$ ratios. This result suggests the presence of at least three components in the mantle sources involved in the different ridge segments. 
$\mathrm{Sr}, \mathrm{Nd}$ isotopic ratios cannot be simply explained by a two-component binary mixing. Moreover Sarda et al. [40] have shown that the primitive ${ }^{4} \mathrm{He} /{ }^{3} \mathrm{He}$ ratios associated to the Discovery mantle plume are restricted to the Central Discovery segment (S3), whereas samples from the Northern Discovery seg- ment have MORB-like compositions (Fig. 3). This observation together with the observed variations in $\mathrm{Sr}$, $\mathrm{Nd}$ and $\mathrm{Pb}$ isotopes (Fig. 4) demonstrates the important point that at least three components should be invoked to explain the source heterogeneity of this area. Consequently, the involvement of

Table 1

Location, Os and Re contents, ${ }^{187} \mathrm{Re} /{ }^{188} \mathrm{Os}$ and ${ }^{187} \mathrm{Os} /{ }^{188} \mathrm{Os}$ ratios measured in MORB from $40^{\circ}-50^{\circ} \mathrm{S}$ segment of the mid-Atlantic Ridge

\begin{tabular}{|c|c|c|c|c|c|c|c|c|c|}
\hline Samples & $\begin{array}{l}\text { Latitude } \\
{ }^{\circ} \mathrm{S}\end{array}$ & $\begin{array}{l}\text { Longitude } \\
{ }^{\circ} \mathrm{W}\end{array}$ & & $\begin{array}{l}\text { Os } \\
\mathrm{ppt}\end{array}$ & $\begin{array}{l}\mathrm{Re} \\
\mathrm{ppb}\end{array}$ & ${ }^{187} \mathrm{Re} /{ }^{188} \mathrm{Os}$ & ${ }^{187} \mathrm{Os} /{ }^{188} \mathrm{Os}$ & $\begin{array}{l}\% \text { blank } \\
\text { correction }\end{array}$ & $\begin{array}{l}\text { Model age } \\
(\mathrm{Ma})\end{array}$ \\
\hline \multicolumn{10}{|l|}{ Segment $S 1: 40^{\circ}-45^{\circ} S$} \\
\hline EW9309 44D-3g & 40.86 & 16.79 & $\mathrm{gl}, \mathrm{pl}$ & 5.78 & 0.91 & 762 & $0.1428(08)$ & 0.3 & 1.308 \\
\hline EW9309 43D-1g & 42.19 & 16.08 & $\mathrm{gl}$ & 1.73 & 0.96 & 2690 & $0.1409(24)$ & 1.7 & 0.328 \\
\hline EW9309 41D-1g (a) & 44.02 & 16.08 & $\mathrm{gl}$ & 2.65 & 1.10 & 1989 & $0.2316(23)$ & -0.7 & 3.182 \\
\hline EW9309 41D-1g (b) & 44.02 & 16.08 & $\mathrm{gl}$ & 2.90 & 0.91 & 1529 & $0.2316(28)$ & 0.1 & 4.137 \\
\hline EW9309 41D-stg & 44.02 & 16.08 & gl & 5.75 & 1.05 & 886 & $0.1841(26)$ & 0.4 & 3.921 \\
\hline EW9309 40D-1g & 44.41 & 15.91 & gl & 5.12 & 2.13 & 1985 & $0.1439(14)$ & 0.5 & 0.535 \\
\hline \multicolumn{10}{|c|}{ Segment $S 2: 45^{\circ}-47.35^{\circ} \mathrm{S}$} \\
\hline EW9309 37D-1g & 45.23 & 15.07 & gl & 5.65 & 0.77 & 658 & $0.1387(12)$ & 0.5 & 1.141 \\
\hline EW9309 36D-1g & 45.57 & 14.71 & $\mathrm{gl}$ & 1.51 & 0.83 & 2667 & $0.1561(45)$ & 1.3 & 0.673 \\
\hline EW9309 34D-1g (a) & 45.85 & 14.19 & gl & 5.85 & 0.59 & 492 & $0.1943(24)$ & 0.2 & 8.312 \\
\hline EW9309 34D-1g (b) & 45.85 & 14.19 & gl & 4.98 & & & $0.1914(18)$ & 0.3 & \\
\hline EW9309 33D-1g (a) & 46.00 & 14.08 & $\mathrm{gl}$ & 12.47 & 0.73 & 279 & $0.1337(07)$ & 0.2 & 1.616 \\
\hline EW9309 33D-1g (b) & 46.00 & 14.08 & $\mathrm{gl}$ & 5.60 & 0.56 & 485 & $0.1314(14)$ & 0.5 & 0.643 \\
\hline EW9309 33D-1g (c) & 46.00 & 14.08 & gl & 4.28 & & & $0.1329(31)$ & 3.5 & \\
\hline EW9309 32D-1g & 46.23 & 13.56 & $\mathrm{gl}, \mathrm{pl}$ & 4.23 & 0.84 & 955 & $0.1482(38)$ & 0.4 & 1.382 \\
\hline EW9309 31D-1g & 46.39 & 13.45 & $\mathrm{gl}$ & 1.45 & 1.21 & 4045 & $0.1619(40)$ & 2.4 & 0.530 \\
\hline EW9309 28D-1g & 46.90 & 13.45 & $\mathrm{gl}, \mathrm{pl}$ & 3.76 & 0.95 & 1220 & $0.1501(12)$ & 0.5 & 1.176 \\
\hline EW9309 28D-3g (a) & 46.90 & 13.45 & $\mathrm{gl}, \mathrm{pl}$ & 3.63 & 0.82 & 1094 & $0.1440(25)$ & 0.5 & 0.977 \\
\hline EW9309 28D-3g (b) & 46.90 & 13.45 & $\mathrm{gl}, \mathrm{pl}$ & 4.19 & & & $0.1412(17)$ & 0.6 & \\
\hline EW9309 26D-1g & 47.35 & 13.40 & $\mathrm{gl}$ & 2.75 & 1.64 & 2879 & $0.1475(23)$ & 1.3 & 0.444 \\
\hline \multicolumn{10}{|c|}{ Segment S3: $47.35^{\circ}-48.5^{\circ} \mathrm{S}$} \\
\hline EW9309 25D-Stg & 47.35 & 10.32 & $\mathrm{gl}$ & 1.84 & 0.44 & 1148 & $0.1490(12)$ & 1.9 & 1.192 \\
\hline EW9309 02D-1g & 47.55 & 10.32 & gl & 1.45 & & & $0.1600(44)$ & 1.4 & \\
\hline EW9309 02D-3g & 47.55 & 10.19 & gl & 3.14 & 0.74 & 1144 & $0.1498(11)$ & 1.6 & 1.238 \\
\hline EW9309 03D-3g & 47.80 & 10.15 & $\mathrm{gl}$ & 1.76 & 1.22 & 3350 & $0.1503(49)$ & 3.8 & 0.432 \\
\hline EW9309 04D-2g & 47.97 & 10.08 & $\mathrm{gl}$ & 4.56 & 0.89 & 941 & $0.1468(27)$ & 0.3 & 1.313 \\
\hline EW9309 04D-3g & 47.97 & 10.08 & $\mathrm{gl}$ & 1.37 & 1.08 & 3800 & $0.1465(37)$ & 1.2 & 0.321 \\
\hline EW9309 05D-5g & 48.24 & 10.00 & gl & 5.22 & 0.93 & 860 & $0.1369(16)$ & 0.5 & 0.747 \\
\hline \multicolumn{10}{|c|}{ Segment $S 4: 48.5^{\circ}-49.2^{\circ} \mathrm{S}$} \\
\hline EW9309 06D-1g & 48.55 & 10.07 & gl & 4.21 & 1.26 & 1452 & $0.1646(50)$ & 5.2 & 1.587 \\
\hline EW9309 07D-1g & 48.76 & 10.07 & $\mathrm{gl}$ & 8.17 & 1.00 & 591 & $0.1592(35)$ & 0.8 & 3.350 \\
\hline EW9309 08D-1g & 48.96 & 9.97 & $\mathrm{gl}$ & 5.01 & 1.16 & 1126 & $0.1660(26)$ & 1.0 & 2.122 \\
\hline EW9309 09D-1g & 49.15 & 9.91 & $\mathrm{gl}$ & 4.98 & 0.75 & 730 & $0.1561(12)$ & 1.1 & 2.457 \\
\hline \multicolumn{10}{|c|}{ Segment S5: $49.2^{\circ}-50^{\circ} \mathrm{S}$} \\
\hline EW9309 10D-3g & 49.25 & 8.14 & $\mathrm{gl}, \mathrm{pl}$ & 1.98 & 1.44 & 3530 & $0.1579(67)$ & 0.3 & 0.539 \\
\hline EW9309 13D-1g & 49.99 & 7.88 & $\mathrm{gl}$ & 1.71 & 0.92 & 2587 & $0.1533(14)$ & 2.7 & 0.629 \\
\hline
\end{tabular}

Effect of blank correction on ${ }^{187} \mathrm{Os} /{ }^{188}$ Os are reported in \%. Model ages are calculated for each sample using the average abyssal peridotite isotopic compisition $\left({ }^{187} \mathrm{Os} /{ }^{188} \mathrm{Os}=0.1262\right)$. gl: glass; pl: presence of plagioclase phenocrysts. 
the plume component cannot solely be responsible for all the observed trace element and isotopic variations. Therefore, in order to discuss the nature of the different components involved in the MORB source, N-MORB and E-MORB have been distinguished in the different figures.

Central Discovery Segment $\left(47.35^{\circ}-48.5^{\circ} \mathrm{S}\right.$, labeled S3): Samples from this segment have high ${ }^{87} \mathrm{Sr} /{ }^{86} \mathrm{Sr},{ }^{206} \mathrm{~Pb} /{ }^{206} \mathrm{~Pb},{ }^{207} \mathrm{~Pb} /{ }^{206} \mathrm{~Pb}$ and ${ }^{208} \mathrm{~Pb} /{ }^{206} \mathrm{~Pb}$ ratios, which correspond to the effect of the plumeridge interaction. With the exception of samples from the dredge 25D, samples from this segment have primitive ${ }^{4} \mathrm{He} /{ }^{3} \mathrm{He}$ signature consistent with the presence of plume material in their source (Fig. 3). Note that, in addition to their MORB-like ${ }^{4} \mathrm{He} /{ }^{3} \mathrm{He}$ ratio, samples from dredge $25 \mathrm{D}$ are also characterized by anomalously high $\mathrm{SiO}_{2}$ (mean: $54.05 \pm 0.05$ wt.\%, see [41]) content for a $\mathrm{MgO}$ content of approximately $7.5 \mathrm{wt} . \%$, very high ${ }^{87} \mathrm{Sr} /{ }^{86} \mathrm{Sr}$ ratios $(0.70580$ to 0.70588 , the highest value measured in this study) and significantly more radiogenic $\mathrm{Pb}$ isotopic compositions relative to other samples from the same segment.

Southern Discovery Segment $\left(48.5^{\circ}-49.2^{\circ} \mathrm{S}\right.$, labeled S4): samples from this segment display a DUPAL-like signature with particularly high ${ }^{87} \mathrm{Sr} /$ ${ }^{86} \mathrm{Sr},{ }^{4} \mathrm{He} /{ }^{3} \mathrm{He}$ and low ${ }^{206} \mathrm{~Pb} /{ }^{204} \mathrm{~Pb}$ associated with high ${ }^{208} \mathrm{~Pb} /{ }^{204} \mathrm{~Pb}$ ratios (i.e., high $\Delta 8 / 4$, which represents the vertical deviation of the ${ }^{208} \mathrm{~Pb} /{ }^{204} \mathrm{~Pb}$ ratio relative to the North Hemisphere Reference Line for a given ${ }^{206} \mathrm{~Pb} /{ }^{204} \mathrm{~Pb}$, as defined by Hart [10]; see Fig. 4b). Previous studies $[8,13,41,44]$ have related the component responsible for the DUPAL signature of Atlantic MORB to fragments of subcontinental lithosphere materials recycled into the convecting mantle.

$\mathrm{N}-\mathrm{MORB}$, southern region $\left(49.2^{\circ}-50^{\circ} \mathrm{S}\right.$, labeled S5): Samples from this segment are the most representative of the depleted part of the upper mantle, having the lowest ${ }^{87} \mathrm{Sr} /{ }^{86} \mathrm{Sr}$ and $\Delta 8 / 4 \mathrm{~Pb}$ values. However, they plot as a parallel trend to the NHRL at higher ${ }^{208} \mathrm{~Pb} /{ }^{204} \mathrm{~Pb}$ in Fig. $4 \mathrm{~b}$, which suggests the presence of an enriched component in their source.

\section{Analytical techniques}

We report Re and Os concentrations and Os isotopic ratios measured in 27 basalts collected in 23 dredges along the MAR between $40^{\circ} \mathrm{S}$ and $50^{\circ} \mathrm{S}$ (lo- cation given in Table 1) aboard the $\mathrm{R} / \mathrm{V}$ Maurice Ewing (EW93-09 cruise of 1993). All the samples have been previously analyzed for trace element compositions and $\mathrm{Pb}, \mathrm{Nd}, \mathrm{Sr}$, isotopic ratios [8,41], and most of them also for $\mathrm{He}, \mathrm{Ne}, \mathrm{Ar}$ [40] and $\mathrm{Hf}$ [42]. Samples were hand-picked fresh glass ships, selected after a thorough observation under a binocular microscope established the absence of plagioclase that could be present within some of the basalts (see Table 1 for the list of samples with plagioclase). To remove any secondary contamination, all samples were leached before crushing and dissolution, following a five step leaching procedure: $\mathrm{H}_{2} \mathrm{O}$ in ultrasonic waves, $0.1 \mathrm{~N} \mathrm{HCl}$ at $80{ }^{\circ} \mathrm{C}(30 \mathrm{~min}), 0.1 \mathrm{~N}$ oxalic acid at $80{ }^{\circ} \mathrm{C}(30 \mathrm{~min}), 9 \mathrm{~N} \mathrm{HBr}$ at $80{ }^{\circ} \mathrm{C}(15-30 \mathrm{~min})$, and $8 \mathrm{~N} \mathrm{HF}$ in ultrasonic waves to remove an eventual redeposit of $\mathrm{SiO}_{2}$. $\mathrm{Re}-\mathrm{Os}$ analyses were done on 2-3 g of powder crushed into an agate mortar. Details of the $\mathrm{Re}-\mathrm{Os}$ solvent extraction technique are given elsewhere [45]. The isotopic ratios were measured on a Finnigan Mat 262 using an ion counter multiplier and negative thermal ionization. Total procedural blanks during the entire course of this study were, for Os, $0.036 \pm 0.008 \mathrm{pg}$ with ${ }^{187} \mathrm{Os} /{ }^{188} \mathrm{Os}=0.43 \pm 0.16$ and for $\mathrm{Re}, 29 \pm 12 \mathrm{pg}$. In-run $2 \sigma$ precisions for the ${ }^{187} \mathrm{Os} /{ }^{188} \mathrm{Os}$ ratios vary between $0.3 \%$ and $4.2 \%$. These values, though higher than the total external reproducibility of $0.13 \%$ obtained on osmium IPGP $1.2 \mathrm{pg} / \mathrm{g}$ standard, are consistent with the lower signal intensity during acquisition and the low Os concentration of samples.

\section{Results}

The concentration and isotope data for all the mid-ocean ridge basalt glasses analyzed are given in Table 1. The osmium concentrations range from 1.37 to $12.47 \mathrm{ppt}$ and rhenium concentrations vary from 436 to 2128 ppt. ${ }^{187} \mathrm{Re} /{ }^{188} \mathrm{Os}$ ratios range from 278.5 to 4045.4 . ${ }^{187} \mathrm{Os} /{ }^{188} \mathrm{Os}$ ratios range from 0.1314 to 0.2316 . Several samples have been analyzed twice or more. All the ${ }^{187} \mathrm{Os} /{ }^{188}$ Os ratios measured are reproducible within the analytical error. In contrast, the variation of Os concentrations in duplicates ranges from $9 \%$ to $191 \%$. Excluding the extreme sample (33D-1 g), the variation is limited to a maximum of $17 \%$. The sample heterogene- 
ity for Os contents reflects probably a nugget effect, that is to say there is a preferential distribution of Os in refractory sulfides or other Os-bearing microinclusions. Sample 33D-1 g has been analyzed three times and the two lowest concentrations measured are quite similar (see Table 1). For this sample, the absence of simple relationship between Os content and ${ }^{187} \mathrm{Os} /{ }^{188} \mathrm{Os}$ ratio suggests that the Os heterogeneity is not related to secondary processes or to a partial leaching procedure but reflects an extreme nugget effect. It also indicates that the Osbearing phases responsible for the "nugget effect" are in isotopic equilibrium within the host glass.

The Os isotopic compositions of mid-oceanic ridge basalts (data from this study and $[15,24,25]$ ) are significantly more radiogenic than abyssal peridotite bulk compositions [23,26-29] and the present-day upper mantle value [30] (Fig. 1). However, most of the MORB Os isotopic compositions overlap the compositions interstitial sulphides found in mantle peridotites $[33,35,36]$. Samples with plagioclase, a constituent with high $\mathrm{Re} / \mathrm{Os}$ ratio which rapidly develops radiogenic ${ }^{187} \mathrm{Os} /{ }^{188} \mathrm{Os}$ ratio [25], display Os isotopic composition within the range defined by the nearby plagioclase-free samples. This result supports either that hand-picking effectively removed plagioclase or that plagioclase has not developed high ${ }^{187} \mathrm{Os} /{ }^{188} \mathrm{Os}$ yet. With the exception of some samples (from the dredges DR34, DR41 and from the $48.5^{\circ}-49.2^{\circ} \mathrm{S}$ segment), the South Atlantic MORB define global linear trends in the ${ }^{187} \mathrm{Os} /{ }^{188} \mathrm{Os}$ vs. $1 /{ }^{188} \mathrm{Os}$ and ${ }^{187} \mathrm{Os} /{ }^{188} \mathrm{Os}$ vs. ${ }^{187} \mathrm{Re}^{188} \mathrm{Os}$ diagrams (Fig. 5) which are consistent with the early results of Schiano et al. [24].

\section{Re-Os behavior in Mid-Ocean-Ridge basalts}

The Os concentrations of the South Atlantic MORB are in the range defined by MORB glasses from other ocean basins $[15,24]$. As illustrated in the $\mathrm{Ni}-\mathrm{Os}$ diagram (Fig. 6), the variation of Os content could be explained mainly by fractional crystallization. The silicates, such as olivine, have very low Os content and the decrease of Os content associated with their formation essentially reflects the formation of sulfides [46]. A fractional crystallization model, starting from a primary melt of $480 \mathrm{ppm} \mathrm{Ni}$ and $400 \mathrm{ppt}$ Os [47], reproduces the MORB dataset as well as the pillows' compositions from DSDP/ODP Hole 504B [48] by crystallizing olivine with $0.02 \%$ to $0.06 \%$ of Os-rich sulfide, which correspond to $\mathrm{D}_{\mathrm{Os}} / \mathrm{D}_{\mathrm{Ni}}=1.35$ and $\mathrm{D}_{\mathrm{Os}} / \mathrm{D}_{\mathrm{Ni}}=3.80$, respectively (see caption of Fig. 6 for details).

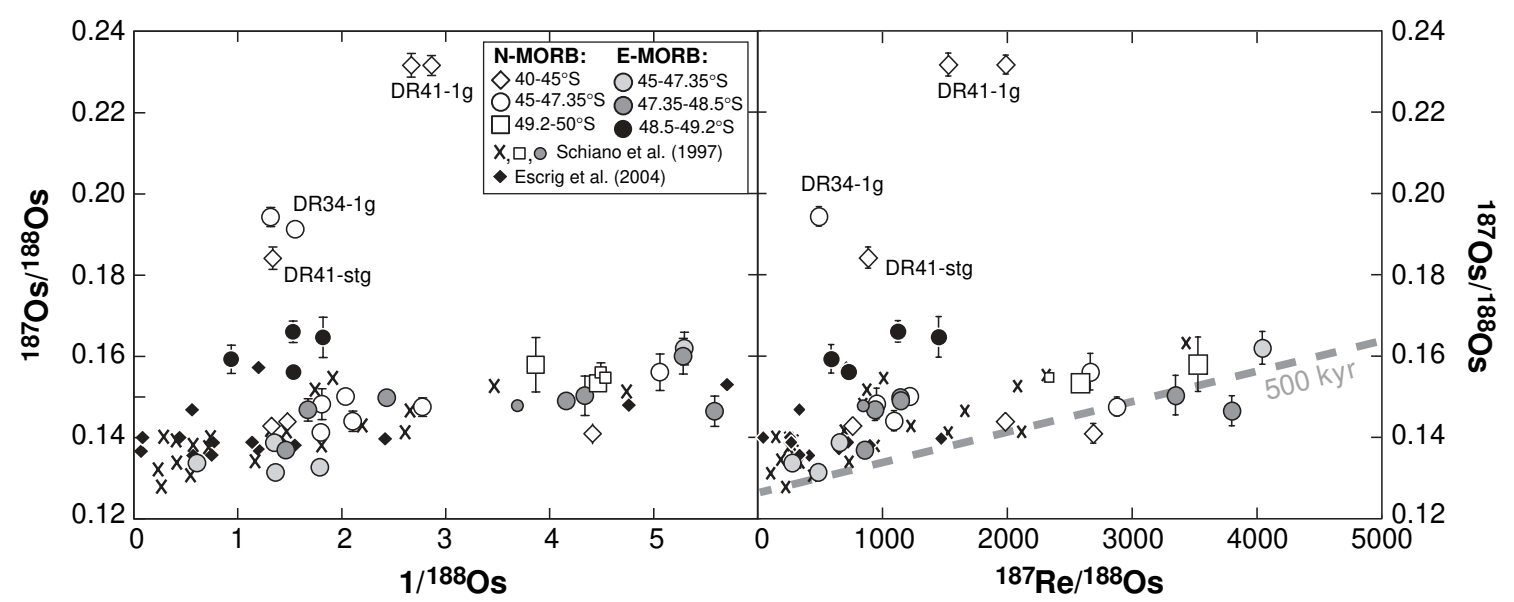

Fig. $5 .{ }^{187} \mathrm{Os} /{ }^{188}$ Os vs. $1 /{ }^{188}$ Os and vs. ${ }^{187} \mathrm{Re} /{ }^{188}$ Os diagrams for MORB. Most of the ${ }^{187} \mathrm{Os} /{ }^{188}$ Os ratios measured in MORB from the South Atlantic ridge define global trend with $1 /{ }^{188} \mathrm{Os}$ and ${ }^{187} \mathrm{Re} /{ }^{188} \mathrm{Os}$ that could represent a binary mixing between a Os-poor and radiogenic component and a Os-rich and unradiogenic component that occured during MORB genesis [24]. Samples from the dredge 41 and 34 define trends distinct from the global trends and their high ${ }^{187} \mathrm{Os} /{ }^{188} \mathrm{Os}$ ratios likely reflect a late contamination process. Most of the South Atlantic MORB plot above the $500 \mathrm{kyr}$ isochron which corresponds to a distance of $17.5 \mathrm{~km}$ from the spreading center using a spreading rate of $35 \mathrm{~mm} /$ year [54]. It is thus unlikely that the MORB ${ }^{187} \mathrm{Os} /{ }^{188} \mathrm{Os}$ ratios reflect post-eruption decay of ${ }^{187} \mathrm{Re}$. 


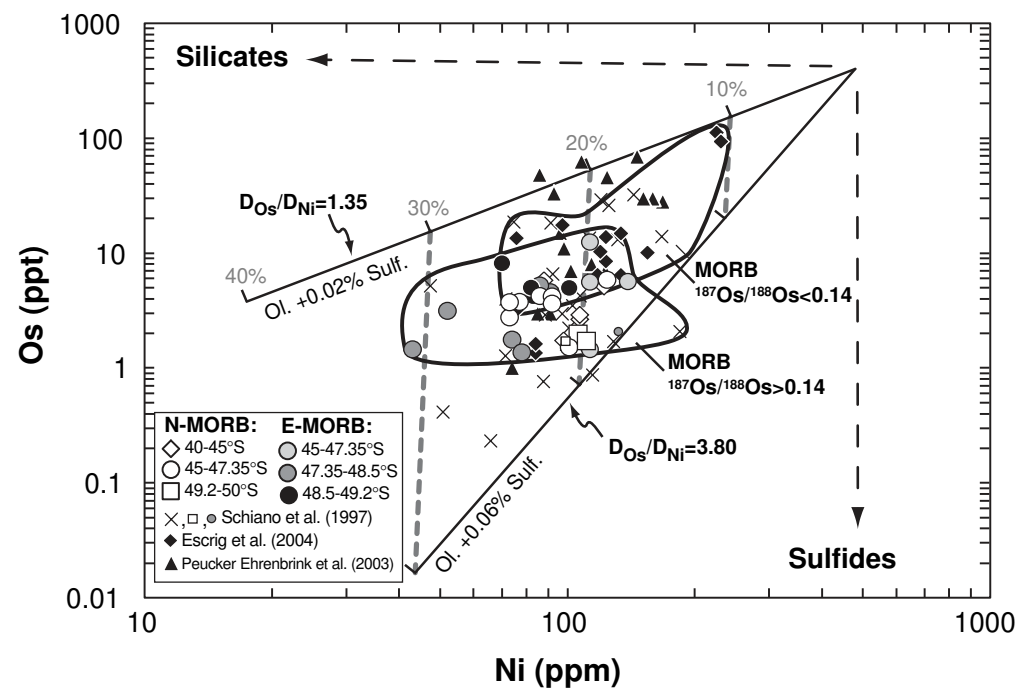

Fig. 6. Ni and Os concentrations in MORB glasses and pillows from the DSDP/OPD Hole 504B. Indian MORB from Escrig et al. [15] are represented by black diamonds and data from Schiano et al. [24] by crosses. Ni contents for samples from [15] are unpublished data). The pillows from Hole 504B [48] are the black triangles. Fractional crystallization curves of olivine with $0.02 \%$ and $0.06 \%$ sulfide are shown, starting from a primary melt with $480 \mathrm{ppm} \mathrm{Ni}$ and $400 \mathrm{ppt}$ Os [47]. Partition coefficients used were $D_{\mathrm{ni}}=7.4$ and $D_{\text {Os }}=0.51$ for olivine [46] and $D_{\mathrm{Ni}}=600 ; D_{\mathrm{Os}}=4.810^{4}$ for Os-rich sulfides [46], which led to $D_{\mathrm{Os}} / D_{\mathrm{Ni}}=1.35$ and $D_{\mathrm{Os}} / D_{\mathrm{Ni}}=3.80$ for $0.02 \%$ and $0.06 \%$ sulfides, respectively. Grey dashed lines correspond to $10 \%, 20 \%$ and $30 \%$ crystallization. Sulfide fractionation produces vertical trends in this plot while olivine fractionation trends are almost horizontal due to the low Os partition coefficient for olivine [46]. For Ni compositions ranging between 70 ppm and $200 \mathrm{ppm}$., MORB with ${ }^{187} \mathrm{Os} /{ }^{188} \mathrm{Os}$ ratios higher than 0.14 have an average Os content of $3.5 \pm 2.4 \mathrm{ppt}$ while those with ${ }^{187} \mathrm{Os} /{ }^{188} \mathrm{Os}$ lower than 0.14 have an average Os content of $12.3 \pm 8.0 \mathrm{ppt}$. The fields for MORB with ${ }^{187} \mathrm{Os} /{ }^{188}$ Os higher and lower than 0.14 are also shown, excluding the aged samples from the Hole 504B and the samples with no Os isotopic composition from Schiano et al. [24].

Most mid-oceanic ridge basalts analyzed in Os studies have Ni contents between 70 and $200 \mathrm{ppm}$ (Fig. 6). Within this range, it appears that MORB with ${ }^{187} \mathrm{Os} /{ }^{188}$ Os ratio higher than 0.14 have average Os contents of $3.5 \pm 2.4 \mathrm{ppt}$ while those with ${ }^{187} \mathrm{Os} /{ }^{188}$ Os lower than 0.14 have average Os contents of $12.3 \pm 8.0 \mathrm{ppt}$. Assuming magma differentiation has a comparable effect on the $\mathrm{Ni}$ and Os contents from one sample to another, such an observation could imply that the primitive magmas of radiogenic MORB have lower Os contents for a given Ni content. Late contamination of the magma by a radiogenic component with low Os content is also a possible explanation. Both hypotheses are consistent with the correlations of ${ }^{187} \mathrm{Os} /{ }^{188} \mathrm{Os}$ with $1 /{ }^{188} \mathrm{Os}$ and ${ }^{187} \mathrm{Re} /{ }^{188} \mathrm{Os}$, which could be interpreted as mixture trends between an Os-poor component with radiogenic ${ }^{187} \mathrm{Os} /{ }^{188} \mathrm{Os}$ and a Os-rich component with unradiogenic ${ }^{187} \mathrm{Os} /{ }^{188}$ Os.

Re concentrations do not present any global or segment-limited relationship with $\mathrm{FeO}$ or $\mathrm{SiO}_{2}$ contents that would suggest a pressure effect on $\mathrm{Re}$ partitioning [49]. The Re concentration increases during crystallization and this is in agreement with a moderate incompatible behavior. This feature is also supported by the correlation of $\mathrm{Re}$ content with HREE, especially with $\mathrm{Yb}$ as previously shown by Sun et al. [50]. The dispersion of Re content observed when plotted versus any index of differentiation suggests that the degree of partial melting and/or the MORB source heterogeneity contribute significantly to the Re variability in MORB.

\section{Discussion}

\subsection{Principal component analyses}

MORB sampled along the $40^{\circ}-50^{\circ} \mathrm{S}$ ridge segment display important variations in $\mathrm{Pb}, \mathrm{Sr}$, and $\mathrm{Nd}$ isotopes that reflect several extreme end-members in the isotopic diagrams and thus involve different mantle components in their mantle sources. Os isotope ratios also vary greatly along the ridge segment and 
samples from the three southernmost ridge segments studied here (S3 to S5) have homogeneous but distinct $\mathrm{Os}, \mathrm{Pb}, \mathrm{Sr}$ and $\mathrm{Nd}$ isotope ratios (Fig. 3) consistent with the presence of distinct components. Thus, in order to examine the relationships between Os isotopes and $\mathrm{Sr}-\mathrm{Nd}-\mathrm{Pb}$ isotopes in the samples and discuss plausible processes at the origin of the observed range of Os isotope ratios, we have performed isotopic multidimensional analyses of our dataset, following the technique described by Allègre et al. [51]. It consists of computing the main elongation directions of the data cloud in a $N$-dimensional space by considering the data deviation from mean isotopic values. Since all the isotopic ratios are not measured with the same precision and present different absolute variation, each isotopic ratio is weighted after normalization to the standard deviation by a correction factor, which takes into account the absolute analytical error. A weight of $1 / 3$ is given to the ${ }^{207} \mathrm{~Pb} /{ }^{204} \mathrm{~Pb}$ ratio when all the other ratios get a weight of 1 [51]. After this correction, a classical principal component analysis (PCA) is applied, which gives the principal directions expressed by the eigenvectors, $V_{\mathrm{i}}$ of the variance-covariance matrix, and the associated eigenvalues $\lambda_{\mathrm{I}}$.

The results obtained for 5-dimensional isotopic space $\left(\mathrm{Pb}^{3}, \mathrm{Sr}\right.$ and $\left.\mathrm{Nd}\right)$, 6-dimensional isotopic space $\left(\mathrm{Pb}^{3}, \mathrm{Sr}, \mathrm{Nd}\right.$ and $\left.\mathrm{Os}\right)$ and 7-dimensional isotopic space $\left(\mathrm{Pb}^{3}, \mathrm{Sr}, \mathrm{Nd}, \mathrm{Os}\right.$ and $\left.\mathrm{Hf}\right)$ are reported in Table 2 and displayed in Fig. 7. In the 5-dimensional isotopic space, most of the dispersion $(92.7 \%)$ can be reduced to two main elongation directions corresponding to variance percentages of $60.8 \%$ and $31.9 \%$, respectively. When Os isotopic ratios are also considered, three principal directions are required to describe more than $90 \%$ of the total variance. These results are illustrated using projections of the data points onto the plane $\left(V_{1}\right.$ and $\left.V_{2}\right)$ and thickness $\left(V_{1}\right.$ and $\left.V_{3}\right)$ views for the 5- and 6-dimensional isotopic spaces (Fig. 7). Projections for the 7-dimensional isotopic space are not shown since the results are similar to those obtained in the 6dimensional space.

Projections of the data onto the plane view (Fig. 7) reveal a structure that almost corresponds to that defined in the ${ }^{87} \mathrm{Sr} /{ }^{86} \mathrm{Sr}$ vs. ${ }^{206} \mathrm{~Pb} /{ }^{204} \mathrm{~Pb}$ diagram (Fig. 4a), with the first principal direction mainly due to ${ }^{87} \mathrm{Sr} /{ }^{86} \mathrm{Sr}$ ratios and the second principal direction to ${ }^{206} \mathrm{~Pb} /{ }^{204} \mathrm{~Pb}$ ratios. The projection of the 6dimensional isotopic space into the 3-dimensional space $\left(V_{1}, V_{2}, V_{3}\right)$ reveals that the Os isotope axis is almost perpendicular to the ${ }^{206} \mathrm{~Pb} /{ }^{204} \mathrm{~Pb}$ axis $\left(93^{\circ}\right)$ and the ${ }^{87} \mathrm{Sr} /{ }^{86} \mathrm{Sr}$ axis $\left(86^{\circ}\right)$. It therefore appears that Os ratios essentially affect the thickness parameter of the data cloud and lead to a projection in the thickness view very similar to the one in the plane view. An important observation to make is that plane views are identical for the 5- and 6-dimensional isotopic spaces and that the Os vector is essentially expressed in the $V_{2}$ and $V_{3}$ directions.

The perpendicularity of the ${ }^{187} \mathrm{Os} /{ }^{188} \mathrm{Os}$ vector to the ${ }^{206} \mathrm{~Pb} /{ }^{204} \mathrm{~Pb}$ and ${ }^{87} \mathrm{Sr} /{ }^{86} \mathrm{Sr}$ vectors indicate either that the Os isotopic compositions are independent from the other isotopic systems or that they provide complementary information on the nature of the mantle components.

\subsection{Os isotopes as tracer of mantle processes}

The discrepancy between abyssal peridotites and MORB (Fig. 1) has been interpreted either as the result of seawater contamination [31], as the effect of in situ decay of ${ }^{187} \operatorname{Re}[25,32]$, as the mixture with old lavas or cumulates [25], or as the expression of mantle chemical heterogeneities [15,24].

The interaction of magma with seawater has been proposed to explain the correlation in the ${ }^{187} \mathrm{Os} /{ }^{188} \mathrm{Os}$ vs. $1 /{ }^{188}$ Os diagram $[31,52]$. In order to increase the ${ }^{187} \mathrm{Os} /{ }^{188} \mathrm{Os}$ ratio of MORB from a mantle-like ${ }^{187} \mathrm{Os} /{ }^{188} \mathrm{Os}$ ratio of 0.126 to 0.135 requires a seawater to magma ratio of $9: 1$, which seems unreasonably

Table 2

Eigenvectors $\left(V_{\mathrm{i}}\right)$, eigenvalues $\left(\lambda_{\mathrm{i}}\right)$, width $(L)$ and thickness $(f)$ parameters obtained for the different isotopic spaces $R^{5},\left(\mathrm{~Pb}^{3}, \mathrm{Sr}, \mathrm{Nd}\right), R^{5},\left(\mathrm{~Pb}^{3}\right.$, $\mathrm{Sr}, \mathrm{Nd}, \mathrm{Os}), R^{5},\left(\mathrm{~Pb}^{3}, \mathrm{Sr}, \mathrm{Nd}, \mathrm{Os}, \mathrm{Hf}\right)$

\begin{tabular}{|c|c|c|c|c|c|c|c|c|c|c|c|c|c|c|c|c|}
\hline$\%$ & $V_{1}$ & $\lambda_{1}$ & $V_{2}$ & $\lambda_{2}$ & $V_{3}$ & $\lambda_{3}$ & $V_{4}$ & $\lambda_{4}$ & $V_{5}$ & $\lambda_{5}$ & $V_{6}$ & $\lambda_{6}$ & $V_{7}$ & $\lambda_{7}$ & $L$ & $f$ \\
\hline$R^{5}$ & 60.8 & 6255 & 31.9 & 3281 & 3.9 & 401 & 2.3 & 234 & 1.1 & 117 & & & & & 0.72 & 0.25 \\
\hline$R^{6}$ & 49.1 & 6276 & 30.7 & 3929 & 14.6 & 1863 & 2.9 & 370 & 1.8 & 233 & 0.9 & 117 & & & 0.79 & 0.54 \\
\hline$R^{7}$ & 56.7 & 8668 & 25.5 & 3902 & 12.3 & 1879 & 2.4 & 373 & 1.7 & 253 & 0.8 & 124 & 06 & 91 & 0.67 & 0.47 \\
\hline
\end{tabular}



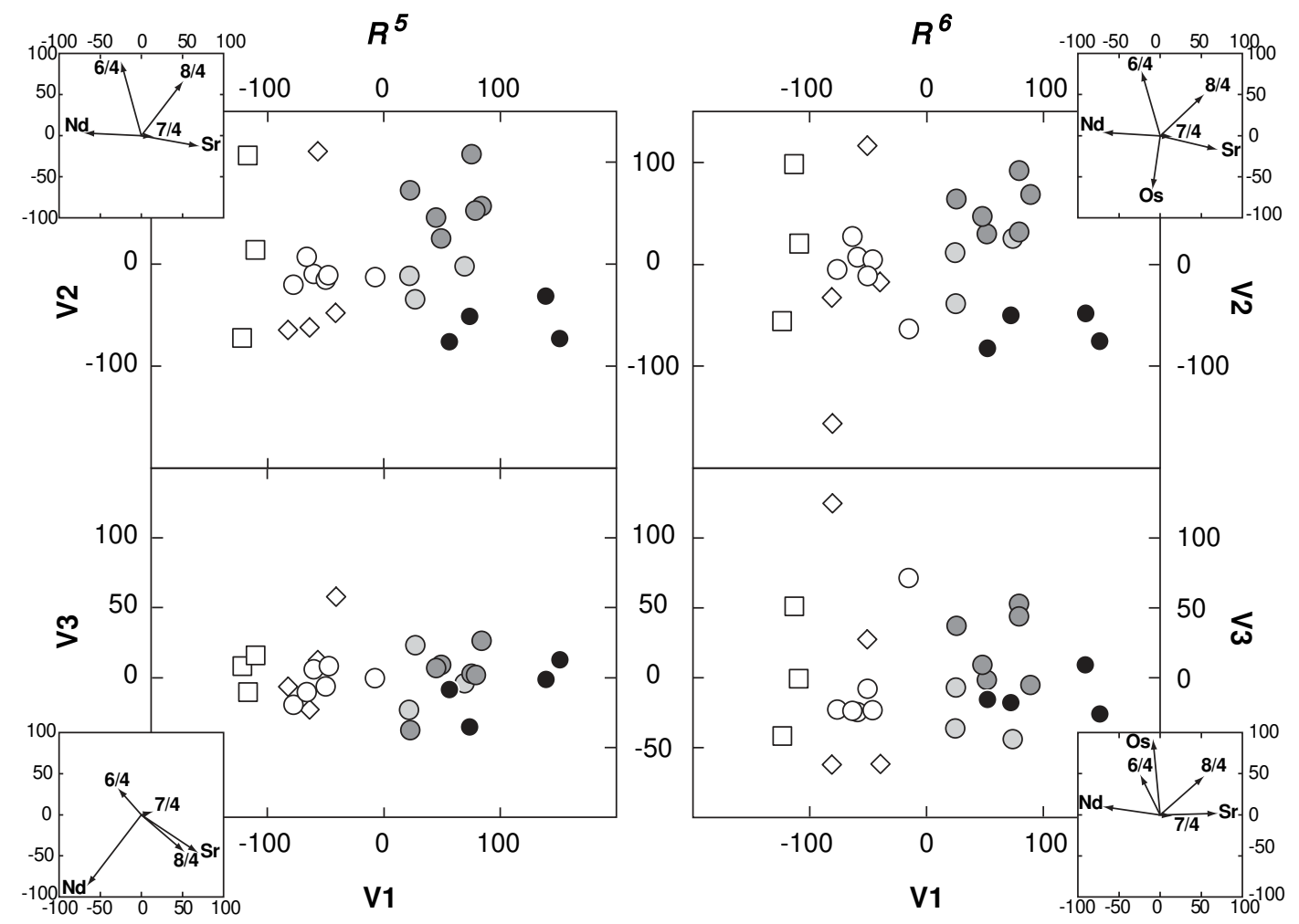

Fig. 7. Projection of MORB analyzed in $R^{5}$ (i.e. $\left.\mathrm{Sr}, \mathrm{Nd}, \mathrm{Pb}^{3}\right)$ and $R^{6}$ (i.e. $\left.\mathrm{Os}, \mathrm{Sr}, \mathrm{Nd}, \mathrm{Pb}^{3}\right)$ isotopic multispace onto the plane $\left(V_{1}-V_{2}\right)$ and thickness $\left(V_{3}-V_{1}\right)$ views. Symbols are given in the previous figures. Axes correspond to the three principal directions $V_{1}, V_{2}, V_{3}$. Arrows in the insets represent the projection of the original isotopic coordinates. Os is for ${ }^{187} \mathrm{Os} /{ }^{188} \mathrm{Os}, \mathrm{Sr}$ is for ${ }^{87} \mathrm{Sr} /{ }^{86} \mathrm{Sr}, \mathrm{Nd}$ for ${ }^{143} \mathrm{Nd} /{ }^{144} \mathrm{Nd}, 6 / 4$ for ${ }^{206} \mathrm{~Pb} /{ }^{204} \mathrm{~Pb}, 7 / 4$ for ${ }^{207} \mathrm{~Pb} /{ }^{204} \mathrm{~Pb}, 8 / 4$ for ${ }^{208} \mathrm{~Pb} /{ }^{204} \mathrm{~Pb}$. Projection of these vectors as well as the dataset onto the plane view is similar for the $R^{5}$ and $R^{6}$ dimensional spaces. The effect of adding Os ratios has only a significant effect on the thickness $f$ of the dataset representation. Os vector is perpendicular to $\mathrm{Sr}\left(86^{\circ}\right)$ and $\mathrm{Pb}\left(93^{\circ}\right)$ vectors and this explains why the $\mathrm{Pb}$ and $\mathrm{Os}$ vectors are opposite in the plane view and quite similar in the thickness view.

high. An initial magma content of 10 ppt Os was used for this calculation together with the seawater composition (10.89 $\mathrm{fg} / \mathrm{g}$ Os and $\left.{ }^{187} \mathrm{Os} /{ }^{188} \mathrm{Os} \sim 1.06\right)$ from Levasseur et al. [53]. It yields a final Os content of $1 \mathrm{ppt}$ with $1 \%$ of the total Os coming from seawater. Due to its high $\mathrm{Sr}$ content (8 ppm $\mathrm{Sr}$ ) and radiogenic $\mathrm{Sr}$ isotopic composition $\left({ }^{87} \mathrm{Sr} /{ }^{86} \mathrm{Sr} \sim 0.709\right)$, such a substantial interaction with seawater should affect significantly the MORB $\mathrm{Sr}$ isotopic composition. Using an initial $\mathrm{Sr}$ content of $150 \mathrm{ppm}$ and a ${ }^{87} \mathrm{Sr} /{ }^{86} \mathrm{Sr}$ ratio of 0.7025 leads to a ${ }^{87} \mathrm{Sr} /{ }^{86} \mathrm{Sr}$ ratio of 0.7046. As illustrated in Fig. 8, except for two samples, the South Atlantic MORB plot above the hyperbolic curve representing the mixture between a hypothetical unradiogenic MORB and seawater. The two samples plotting close to the seawater-magma mixing curve have $\mathrm{Pb}$ isotopic compositions consistent with the $\mathrm{Sr}$ isotopic variations that cannot be related to seawater interaction. In addition, the high ${ }^{87} \mathrm{Sr} /{ }^{86} \mathrm{Sr}$ ratios measured in the South Atlantic MORB are attributed to mantle metasomatism or plume-ridge interaction rather than to seawater contamination [8]. Those results suggest that, if interaction with seawater occurred during magma ascent, it is not responsible for the radiogenic ${ }^{187} \mathrm{Os} /{ }^{188} \mathrm{Os}$ ratios measured in the South Atlantic MORB.

Due to their high $\mathrm{Re} /$ Os ratio, mid-oceanic ridge basalts rapidly develop radiogenic ${ }^{187} \mathrm{Os} /{ }^{188}$ Os ratios and post-eruption decay of ${ }^{187} \mathrm{Re}$ could have a significant effect on the Os MORB isotopic composition. Despite what has been proposed earlier [32], our new dataset, combined with the Central Indian ridge 


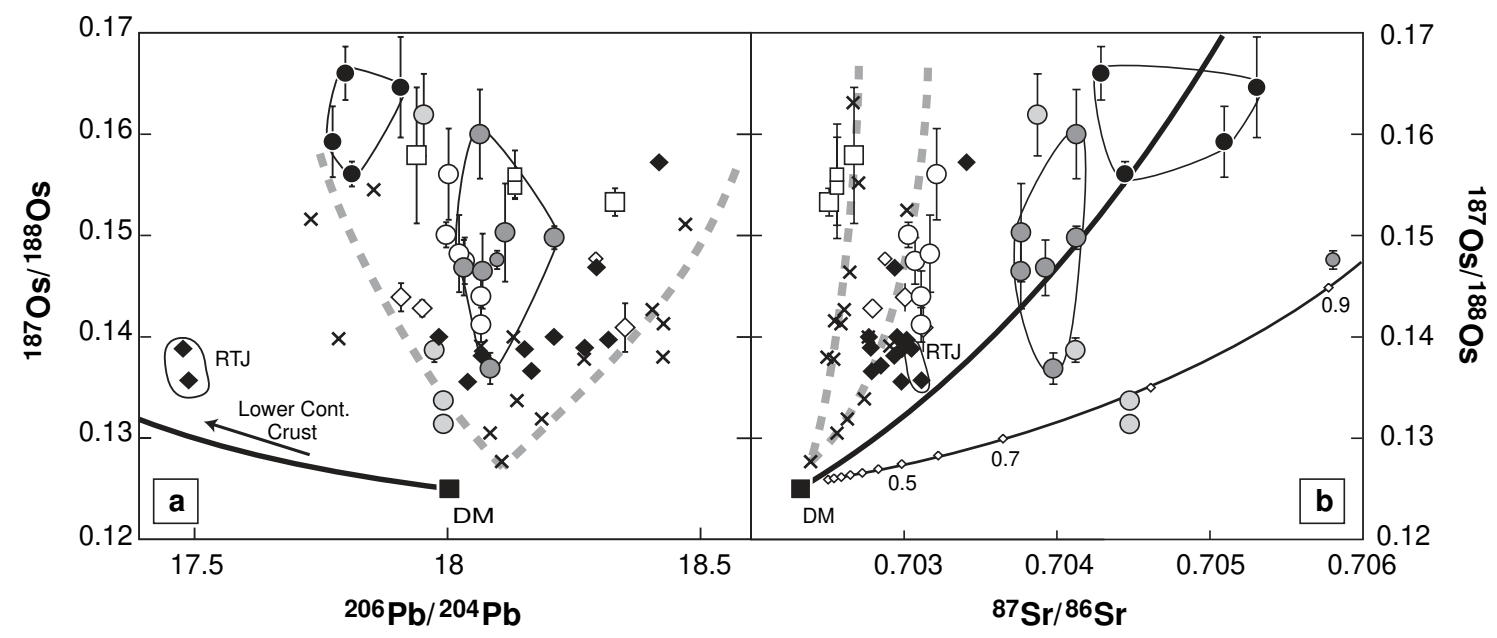

Fig. 8. ${ }^{187} \mathrm{Os} /{ }^{188} \mathrm{Os}$ vs. ${ }^{206} \mathrm{~Pb} /{ }^{204} \mathrm{~Pb}$ (a) and vs. ${ }^{87} \mathrm{Sr} /{ }^{86} \mathrm{Sr}$ (b) diagrams. Symbols are given in Fig. 4. Thick grey dashed lines correspond to mixing hyperbolas previously defined by MORB glasses from the three oceans [24]. Results for MORB from the central Indian ridge, the Rodriguez triple junction (RTJ) and the $39^{\circ}-41^{\circ}$ E SWIR segment suggest than the mixture of depleted mantle (DM) with an extreme DUPAL component thought to be lower continental crust is more curved (thick black hyperbola) [15]. The mixing curve between an unradiogenic magma (10 ppt Os and ${ }^{187} \mathrm{Os} /{ }^{188} \mathrm{Os} \sim 0.126 ; 150 \mathrm{ppm} \mathrm{Sr}$ and $\left.{ }^{87} \mathrm{Sr} /{ }^{86} \mathrm{Sr} \sim 0.7025\right)$ and seawater $\left(10.89 \mathrm{fg} / \mathrm{g}\right.$ Os and ${ }^{187} \mathrm{Os} /{ }^{188} \mathrm{Os} \sim 1.06[53]$; $8 \mathrm{ppm} \mathrm{Sr}$ and ${ }^{87} \mathrm{Sr} /{ }^{86} \mathrm{Sr} \sim 0.709$ ) is also shown in the ${ }^{187} \mathrm{Os} /{ }^{188} \mathrm{Os}$ vs. ${ }^{87} \mathrm{Sr} /{ }^{86} \mathrm{Sr}$ diagram with $10 \%$ increments. In the ${ }^{187} \mathrm{Os} /{ }^{188} \mathrm{Os}$ vs. ${ }^{206} \mathrm{~Pb} /{ }^{204} \mathrm{~Pb}$ diagram, the South Atlantic samples as well as the central Indian MORB from Escrig et al. [15] plot between the two trends defined by [24], implying the involvement of several components in the MORB source. It appears that, within a segment, variable ${ }^{206} \mathrm{~Pb} /{ }^{204} \mathrm{~Pb}$ ratios are generally associated with quite homogeneous ${ }^{187} \mathrm{Os} /{ }^{188} \mathrm{Os}$ ratios and vice versa, which is consistent with the results of the multispace analysis of Fig. 6. In ${ }^{187} \mathrm{Os} /{ }^{188} \mathrm{Os}$ vs. ${ }^{87} \mathrm{Sr} /{ }^{86} \mathrm{Sr}$ diagram, the N-MORB samples plot on the two mixing trends identified by Schiano et al. [24] while EMORB show a shift toward radiogenic value due to the presence of an enriched component (plume material or low $\mu$ component).

MORB analyses [15], reveals the absence of distinction between the different Oceans and confirms the absence of relationship between the spreading rate and the Os isotopic ratio as shown by Gannoun et al. [25]. Using the measured ${ }^{187} \mathrm{Re} /{ }^{188} \mathrm{Os}$ ratios and the mean abyssal peridotite ${ }^{187} \mathrm{Os} /{ }^{188} \mathrm{Os}$ ratio of 0.1262 , a model age has been calculated for each sample and converted into a distance to the ridge axis using a spreading rate of $35 \mathrm{~mm} /$ year [54]. The lowest calculated age of $328 \mathrm{kyr}$ is equivalent to $11.5 \mathrm{~km}$ from the ridge axis, which is too high to be considered as an eruption age. In general, as shown in Fig. 5, most of the South Atlantic MORB have model ages higher than $500 \mathrm{kyr}$, corresponding to a distance of $17.5 \mathrm{~km}$ from the spreading center. In regards to those calculations, it is unlikely that the MORB ${ }^{187} \mathrm{Os} /{ }^{188} \mathrm{Os}$ ratios reflect post-eruption decay of ${ }^{187} \mathrm{Re}$.

In a recent study, Gannoun et al. [25] have shown that the different constituent phases of two mid-oceanic ridge basalts, including the glass rim, define positive correlations in the ${ }^{187} \mathrm{Os} /{ }^{188} \mathrm{Os}$ vs. ${ }^{187} \mathrm{Re} /{ }^{188} \mathrm{Os}$ diagram, which could be interpreted as crystallization ages. However, the Re-Os ages for those two samples are significantly higher than the ages based on the distance from the ridge axis and on the ${ }^{230} \mathrm{Th}-{ }^{226} \mathrm{Ra}$ data. Gannoun et al. [25] suggested that all the minerals they analyzed could be xenocrysts and that the pseudoisochron may reflect a previous crystallization event. The fact that the glass Os isotopic composition lies on the correlation defined by the minerals would thus imply a shallow level contamination of the magma by assimilation of the radiogenic minerals. Olivine and plagioclase are the two phases more radiogenic than the glass rim that could be responsible for its high ${ }^{187} \mathrm{Os} /{ }^{188}$ Os ratio. Even though the assimilation of olivine which is a Ni-rich but Os-poor phase could explain the low Os content for a given Ni content, the major element compositions of the radiogenic MORB do not show evidence for late assimilation of olivine.

The assimilation of radiogenic material cannot however be completely ruled out, especially for the two samples from the dredge 41 which define steep linear trends in the ${ }^{187} \mathrm{Os} /{ }^{188} \mathrm{Os}$ vs. $1 /{ }^{188} \mathrm{Os}$ and vs. 
${ }^{187} \mathrm{Re} /{ }^{188}$ Os diagrams. The sample DR34-1 g also displays a very radiogenic ${ }^{187} \mathrm{Os} /{ }^{188} \mathrm{Os}$ ratio associated with a relatively high Os content, and plots close to the trends defined by the samples of the dredge 41 . Those trends strongly differ from the trends defined by the other samples, which suggests they are related to separate processes. All the other radiogenic samples analyzed in this study have either a low Os content and plot on the global trend in the Fig. 5 or belongs to the $48.5^{\circ}-49.2^{\circ} \mathrm{S}$ segment which has a pronounced DUPAL signature. The assimilation of radiogenic material does not explained the Agulhas FZ effect on the Os isotopic ratios and the compositions of the DUPAL segment (see below) which strongly indicate that the MORB Os isotopic ratios reflect mantle processes.

Two distinct processes affecting the MORB mantle source have to be considered as a possible source for the radiogenic Os ratios measured in MORB: the mantle metasomatism responsible for the presence of radiogenic interstitial sulphides in peridotites and the recycling through the subduction zones of radiogenic crustal components with low Os content. Both processes could explain the correlation in the ${ }^{187} \mathrm{Os} /{ }^{188} \mathrm{Os}$ vs. $1 /{ }^{188}$ Os diagram defined by mid-oceanic ridge basalts. If interstitial sulphides are present in the MORB source, they increase significantly the bulk $\mathrm{S}$ content of peridotite which lower the magma's abundance in platinum group elements at a given melting degree [55]. The contribution of interstitial sulphides to the magma should be higher than that of the sulphides trapped inside silicates. The fact that the interstitial sulphides are radiogenic in Os and Ni-rich could explain the radiogenic MORB compositions and the depletion in Os relative to $\mathrm{Ni}$.

The presence of recycled components in the MORB source has also been proposed to explain the correlation of ${ }^{187} \mathrm{Os} /{ }^{188} \mathrm{Os}$ ratios with the inverse of Os content [24]. The recycled oceanic crust and the sediments have indeed radiogenic ${ }^{187} \mathrm{Os} /{ }^{188} \mathrm{Os}$ ratios together with low Os content and their recycling into the Earth's mantle could produce chemical heterogeneities responsible for the MORB osmium isotopic variations.

The mantle source of the South Atlantic N-MORB appears to have been metasomatised and several recycled components have been identified in the source of the South Atlantic E-MORB [8,41]. In the following sections, we discuss the origin of the high
${ }^{187} \mathrm{Os} /{ }^{188} \mathrm{Os}$ ratios measured in the different ridge segments using trace element and $\mathrm{Pb}-\mathrm{Sr}-\mathrm{Nd}$ isotopic ratios.

\subsection{Mantle heterogeneities inferred from osmium isotopes}

The first large-scale Os isotopic systematic investigation of MORB [24] has shown that MORB glasses from the main ocean basins define two distinct trends in the isotopic diagrams from a common unradiogenic Os component, identified as the depleted upper mantle, to two distinct radiogenic Os components (Fig. 8). The component characterized by radiogenic ${ }^{206} \mathrm{~Pb} /{ }^{204} \mathrm{~Pb}$ and ${ }^{187} \mathrm{Os} /{ }^{188} \mathrm{Os}$ ratios shows characteristics that might be ascribed to the presence of layers of recycled oceanic crust in the mantle source of MORB, whereas the component with low ${ }^{206} \mathrm{~Pb} /{ }^{204} \mathrm{~Pb}$ and high ${ }^{187} \mathrm{Os} /{ }^{188} \mathrm{Os}$ ratios is typified by Indian Ocean samples and seems to be related to the 'DUPAL' or 'LOMU' component that contaminates the Indian depleted upper mantle.

While plotting close to the Indian trend in the $\mathrm{Sr}-$ Os isotopic diagram (Fig. 8b), the MORB from the Central Indian ridge [15] plot between the two distinct trends in the $\mathrm{Pb}-\mathrm{Os}$ isotopic diagram (Fig. 8a). Such a result requires the presence of at least three components in the Indian MORB mantle source [15]. It also implies that the Indian trend previously identified [24] represents a mixing curve between the depleted upper mantle and an extreme DUPAL (or LOMU) component rather than a mixing trend common to all Indian MORB. The Os isotopic compositions of MORB from the Rodriguez Triple Junction and the $39^{\circ}-41^{\circ}$ E SWIR segment [15] even support that such a mixing trend is more curved, towards less radiogenic ${ }^{187} \mathrm{Os} /{ }^{188} \mathrm{Os}$ and ${ }^{206} \mathrm{~Pb} /{ }^{204} \mathrm{~Pb}$ ratios (Fig. 8a).

In the $\mathrm{Sr}$-Os diagram (Fig. 8b), although N-MORB plot along the trends define by Schiano et al. [24], the South Atlantic E-MORB are shifted toward more radiogenic ${ }^{87} \mathrm{Sr} /{ }^{86} \mathrm{Sr}$ values due to the interaction with the Discovery mantle plume or to the LOMU component. The involvement of these mantle components is not obvious in the $\mathrm{Pb}-\mathrm{Os}$ diagram. Indeed, results from the isotopic multidimensional analysis indicate that the isotopic diagrams involving ${ }^{87} \mathrm{Sr} /{ }^{86} \mathrm{Sr}$ ratios are the most useful in distinguishing between the different ridge segment signatures where- 
as the ${ }^{206} \mathrm{~Pb} /{ }^{204} \mathrm{~Pb}$ vs. ${ }^{187} \mathrm{Os} /{ }^{188} \mathrm{Os}$ diagram is not as diagnostic since these two isotopic ratios define the two axes of the plane perpendicular to the main principal direction. The South Atlantic MORB plot however between the two trends in the $\mathrm{Pb}-\mathrm{Os}$ diagram (Fig. 8a), which can be interpreted to reflect the presence of at least three components in the South Atlantic MORB source.

The absence of a systematic relationship between ${ }^{187} \mathrm{Os} /{ }^{188} \mathrm{Os}$ and the other isotopic ratios obscures the origin of the MORB radiogenic Os ratios. It is likely that several processes are involved. Using the global MORB Os variation as well as the geochemical distinction made above, we discuss below the effects of the various mantle processes and recycled components on the MORB Os isotopic compositions.

\subsubsection{Metasomatism of the asthenospheric mantle}

$\mathrm{N}-M O R B$ from the $40^{\circ}-45^{\circ} \mathrm{S}, 45^{\circ}-47.35^{\circ} \mathrm{S}$ and $49.2^{\circ}-50^{\circ} \mathrm{S}$ segments plot along trends that extend toward high ${ }^{206} \mathrm{~Pb} /{ }^{204} \mathrm{~Pb}$ but low ${ }^{87} \mathrm{Sr} /{ }^{86} \mathrm{Sr}$ compositions (Fig. 4) which therefore cannot be attributed to an interaction with the Discovery plume. The absence of Discovery plume material in the source of $\mathrm{N}$ -
MORB is also supported by their trace element compositions clearly different from E-MORB [41]. They display, however, relative $\mathrm{Nb}$ depletions and thus high $\mathrm{Ba} / \mathrm{Nb}, \mathrm{La} / \mathrm{Nb}$ and $\mathrm{K} / \mathrm{Nb}$ ratios, which differ from typical N-MORB composition. Such trace element features support the hypothesis of the mantle source contamination by percolation of sediment-derived melts [41].

LeRoux et al. [41] have suggested that the contamination process responsible for the Southern Mid-Atlantic Ridge N-MORB isotopic characteristics may be related to a long-lived subduction zone during Devonian-Mesozoic times. Considering the oceanic crust was 150 -Myr-old when it was subducting yields a formation age of around $500 \mathrm{Myr}$ relative to present. On the basis of the $\mathrm{Pb}$ and $\mathrm{Sr}$ evolution model used by Rëhkamper and Hofmann [12], the isotopic compositions of a young recycled oceanic crust (ROC) are not consistent with the observed $\mathrm{Pb}$ ratios. Using the model of Rehkämper and Hofmann [12], we report in Fig. 9 the mixing curves delineating the locus of mixtures of the depleted mantle (DM) with $1.5-\mathrm{Ga}$ recycled oceanic crust (ROC) and variable amounts of ancient pelagic sediments. Large proportions $(25 \%-$

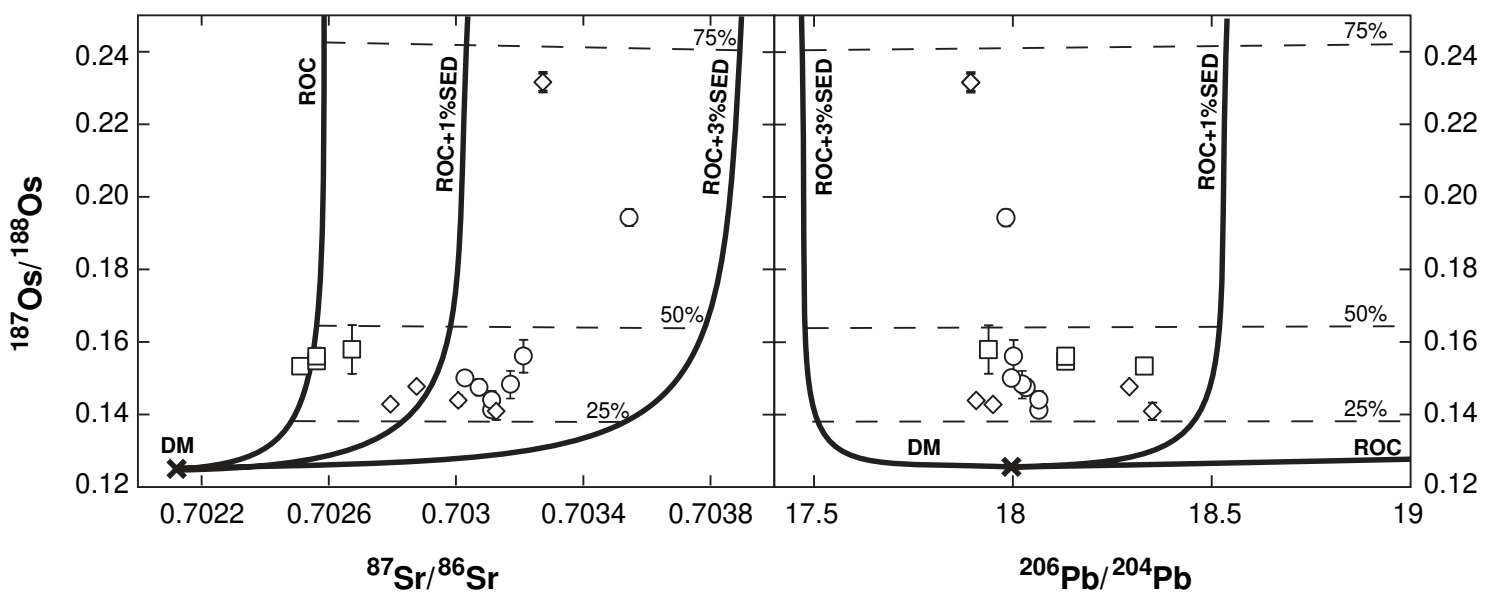

Fig. 9. ${ }^{187} \mathrm{Os} /{ }^{188} \mathrm{Os}$ vs. ${ }^{87} \mathrm{Sr} /{ }^{86} \mathrm{Sr}$ (a) and vs. ${ }^{206} \mathrm{~Pb} /{ }^{204} \mathrm{~Pb}$ (b) diagrams for South Atlantic N-MORB. Mixing curves of depleted mantle with recycled oceanic crust and variable proportions of sediments are calculated using the following values: 1. Mixing of Depleted Mantle (DM: $\left.\mathrm{Os}=3 \mathrm{ppb},{ }^{187} \mathrm{Os} /{ }^{188} \mathrm{Os}=0.125, \mathrm{Sr}=11.3 \mathrm{ppm},{ }^{87} \mathrm{Sr} /{ }^{86} \mathrm{Sr}=0.70214, \mathrm{~Pb}=0.05 \mathrm{ppm},{ }^{206} \mathrm{~Pb} /{ }^{204} \mathrm{~Pb}=17.77\right)$ with 1.5 -Ga recycled oceanic crust (ROC: $\mathrm{Os}=0.01 \mathrm{ppb},{ }^{187} \mathrm{Os} /{ }^{188} \mathrm{Os}=12, \mathrm{Sr}=113 \mathrm{ppm},{ }^{87} \mathrm{Sr} /{ }^{86} \mathrm{Sr}=0.7026, \mathrm{~Pb}=0.3 \mathrm{ppm},{ }^{206} \mathrm{~Pb} /{ }^{204} \mathrm{~Pb}=22.4$ ); 2 . Mixing of $\mathrm{DM}$ with $1.5-\mathrm{Ga}$ recycled oceanic crust plus $1 \% 1.5$-Ga pelagic sediment (SED: $\mathrm{Os}=0.025 \mathrm{ppb},{ }^{187} \mathrm{Os} /{ }^{188} \mathrm{Os}=2, \mathrm{Sr}=300 \mathrm{ppm},{ }^{87} \mathrm{Sr} /{ }^{86} \mathrm{Sr}=0.7203, \mathrm{~Pb}=55 \mathrm{ppm}$, ${ }^{206} \mathrm{~Pb} /{ }^{204} \mathrm{~Pb}=16.7$ ); 3. Mixing of DM with 1.5 -Ga recycled oceanic crust plus $3 \% 1.5$-Ga pelagic sediment. The supposed Os isotopic composition of the recycled component corresponds to ${ }^{187} \mathrm{Re} /{ }^{188} \mathrm{Os}$ to the order of 500 for ROC and 50 for SED. The Pb isotopic composition of ROC is computed using a two stage evolution as defined by [65] with $\mu_{1}=8.1$ and $\mu_{2}=24$. The isotopic composition for DM is taken from the most depleted MORB of the South Atlantic Ridge [66]. The other isotopic compositions are obtained using the calculation of [12]. Dotted lines represent $25 \%, 50 \%$ and $75 \%$ of recycled component added to DM. 
$50 \%$ ) of recycled oceanic crust with a maximum of $3 \%$ of pelagic sediment are required to account for most of the observed N-MORB isotopic variations. These proportions are likely to be significantly lower since recycled components have higher fertility than mantle peridotites. As an example, recycled oceanic crust occurring as pyroxenite or eclogite rocks in the mantle would melt preferentially by a factor of $\sim 4$ over peridotite [56]. Nevertheless, even without considering Os isotopes, the concentrations used by Rehkämper et al. [12] for the three components (depleted mantle, recycled oceanic crust and sediments) do not enable a calculation of $\mathrm{Sr}$ and $\mathrm{Pb}$ isotopic compositions of a given sample with a unique set of mixing proportions. Evaluating the concentrations of the different components remains a difficult task, mostly because the effects of subduction-related processes remain a matter of debate, especially for Os. In addition, the contamination process affecting the depleted mantle is identified as metasomatism by melt percolation rather than mixture with solid recycled components [41].

$\mathrm{N}-M O R B$ from the $40^{\circ}-45^{\circ} \mathrm{S}$ and $45^{\circ}-47.35^{\circ} \mathrm{S}$ segments have similar $\mathrm{Sr}$ and $\mathrm{Pb}$ isotopic variations (Fig. 4) and both have a large range of Os isotopic compositions (Fig. 8). MORB from the $49.2^{\circ}-50^{\circ} \mathrm{S}$ segment display significantly lower ${ }^{208} \mathrm{~Pb} /{ }^{204} \mathrm{~Pb}$ and ${ }^{87} \mathrm{Sr} /{ }^{86} \mathrm{Sr}$ ratios for a similar ${ }^{206} \mathrm{~Pb} /{ }^{204} \mathrm{~Pb}$ range which reflects a lower sedimentary contribution in their source. They also have Os isotopic ratios more radiogenic than most of the N-MORB of the two other segments. This result contrasts with the observation that the sedimentary contribution in their source is the lowest of the area and suggests that their radiogenic Os isotopic ratios are unrelated to the sedimentary contribution.

All the samples from the $49.2^{\circ}-50^{\circ} \mathrm{S}$ segment as well as some Os radiogenic samples from the two other N-MORB segments have low Os contents relative to their $\mathrm{Ni}$ contents (Fig. 6), which may be attributed to the presence of interstitial Ni-rich sulphides in their peridotitic source. The interstitial sulphides are generally associated with non-extracted mantle partial melts [33-35] and their emplacement could be related to the mantle metasomatism event that has affected the local upper mantle. Because they are interstitial, the radiogenic sulphides should contribute more to the magma than the unradiogenic sulphides trapped in silicates. The amount of radiogenic interstitial sulphides in the metasomatised peridotite would thus determine how radiogenic is the MORB at a given melting degree as well as it Os content [55]. In metasomatised peridotites, the amount of interstitial sulphides is controlled by the contribution of mantle partial melts to the metasomatitic agent while the South Atlantic N-MORB Pb-Sr-Nd isotopic compositions are controlled by sediment-derived fluids [41]. Variable contributions of mantle melts and sediment-derived component to the metasomatitic agent could explain the apparent decoupling along the ridge between the ${ }^{187} \mathrm{Os} /{ }^{188} \mathrm{Os}$ ratios and the other isotopic ratios. This hypothesis would require that the southernmost N-MORB segment has been more affected by mantle melt percolation than by a sediment-derived fluid and explains its relatively low ${ }^{208} \mathrm{~Pb} /{ }^{204} \mathrm{~Pb}$ and ${ }^{87} \mathrm{Sr} /{ }^{86} \mathrm{Sr}$ ratios and high ${ }^{187} \mathrm{Os} /{ }^{188} \mathrm{Os}$ ratios associated to low Os contents.

\subsubsection{Plume-ridge interaction}

The current location of the Discovery mantle plume is estimated to lie off-ridge, nearby the Discovery seamount at the east of the ridge. On the basis of relatively primitive ${ }^{4} \mathrm{He} /{ }^{3} \mathrm{He}$ ratios [40], the maximum effect of the plume can be located in the central segment of the Discovery Anomaly, between the Agulhas FZ and the $48.5^{\circ} \mathrm{S}$ offset. E-MORB from this segment defines isotopic trends toward the Discovery tablemount composition (Fig. 4), which is consistent with a dominant contribution of plume material in the source. They display relatively homogeneous ${ }^{87} \mathrm{Sr} /{ }^{86} \mathrm{Sr}$ ratios, with the exception of samples from dredge $25 \mathrm{D}$, associated with variable ${ }^{206} \mathrm{~Pb} /{ }^{204} \mathrm{~Pb}$ and ${ }^{187} \mathrm{Os} /{ }^{188}$ Os ratios (Figs. 3 and 7 ). Most of the EMORB from the Central Discovery segment $\left(47.35^{\circ}-48.5^{\circ} \mathrm{S}\right)$ have radiogenic ${ }^{187} \mathrm{Os} /{ }^{188} \mathrm{Os}$ ratios associated with Os content significantly lower than the unradiogenic MORB (Fig. 5). This result supports the contribution of an Os-poor component with radiogenic ${ }^{187} \mathrm{Os} /{ }^{188} \mathrm{Os}$ ratio such as recycled materials present in the mantle plume. Nevertheless, these MORB do not define trends in the ${ }^{187} \mathrm{Os} /{ }^{188} \mathrm{Os}$ vs. $1 /{ }^{188} \mathrm{Os}$ and vs. ${ }^{187} \mathrm{Re} /{ }^{188}$ Os diagrams (Fig. 5), illustrating that the processes affecting the mantle beneath the ridge are more complicated than a simple binary mixture of mantle sources. In the Ni-Os diagram (Fig. 6), E-MORB from the Central Discovery seg- 
ment have low Os contents together with low $\mathrm{Ni}$ contents, features likely to reflect the effect of differentiation.

Except for the sample from dredge 25D with a MORB-like ${ }^{4} \mathrm{He} /{ }^{3} \mathrm{He}$ signature, ${ }^{187} \mathrm{Os} /{ }^{188} \mathrm{Os}$ ratios decrease from the Agulhas FZ toward the South, down to unradiogenic values $(0.1369 \pm 16$ for EW9309 05D) (Fig. 3). Such a variation is coherent with the preferential plume flow model proposed by Douglass et al. [8] in order to explain the observed isotopic signatures in this area. In this model, the lateral flow of plume material is controlled by the sublithospheric topography. The steep slope across the Agulhas FZ induces a preferential flow southward across the fracture zone rather than eastward toward the spreading center of the Northern Discovery segment (S2), which explains the fact that the most enriched signature is observed just south of the fracture zone.

With regard to the Northern Discovery segment (S2), three samples have high ${ }^{87} \mathrm{Sr} /{ }^{86} \mathrm{Sr}$ and $(\mathrm{La} /$ $\mathrm{Sm})_{N}$ ratios and, in trace element ratio diagrams, plot in between N-MORB and E-MORB samples from the Central and Southern Discovery segments. Isotopically, these samples have ${ }^{87} \mathrm{Sr} /{ }^{86} \mathrm{Sr}$ and ${ }^{187} \mathrm{Os} /{ }^{188}$ Os compositions similar to the Central Discovery segment samples, with the exception of sample $33 \mathrm{D}-1 \mathrm{~g}$ which has the lowest ${ }^{187} \mathrm{Os} /{ }^{188} \mathrm{Os}$ ratios measured in this study. Their MORB-like ${ }^{4} \mathrm{He} /{ }^{3} \mathrm{He}$ ratios and relatively lower ${ }^{206} \mathrm{~Pb} /{ }^{204} \mathrm{~Pb}$ ratios may suggest the $\mathrm{He}$ and $\mathrm{Pb}$ ratios are less sensitive to plume-ridge interaction or the involvement of another component with radiogenic $\mathrm{Os}$ and $\mathrm{Sr}$ isotopic composition but low ${ }^{206} \mathrm{~Pb} /{ }^{204} \mathrm{~Pb}$ ratio. As discussed above, contamination of the local depleted upper mantle can account for the observed N-MORB isotopic variations. Accordingly, addition of significant amounts of sediment-derived component to the plume material could be responsible for the low ${ }^{206} \mathrm{~Pb} /{ }^{204} \mathrm{~Pb}$ measured in the three E-MORB samples from the Northern Discovery segment. Another significant feature is that the two samples (33D-1 $\mathrm{g}$ and $37 \mathrm{D}-1 \mathrm{~g}$ ) with low ${ }^{187} \mathrm{Os} /{ }^{188} \mathrm{Os}$ ratios have $\mathrm{Na}_{8}$ values among the highest of the ridge segment. Thus, a significantly higher contribution of peridotite in their source could explain their low ${ }^{187} \mathrm{Os} /{ }^{188} \mathrm{Os}$ associated with a relatively high Os content as well as their low ${ }^{206} \mathrm{~Pb} /{ }^{204} \mathrm{~Pb}$ and MORB-like ${ }^{4} \mathrm{He} /{ }^{3} \mathrm{He}$ ratios.
In summary, ${ }^{187} \mathrm{Os} /{ }^{188} \mathrm{Os}$ ratios of MORB from the Southern Mid-Atlantic Ridge appear to be essentially governed by the presence of recycled materials in the source, notably in the Central Discovery segment where injection of plume-derived material strongly affects the composition of the erupted basalts. In the Northern Discovery segment where at least two of the three involved components are characterized by radiogenic Os compositions, the origin of the Os signature of MORB is more difficult to decipher because the compositions of the melts derived from the different components remain poorly constrained.

\subsubsection{Nature of the LOMU component}

The Southern Discovery segment, delimited by the $48.5^{\circ} \mathrm{S}$ offset to the North and the $49^{\circ} \mathrm{S}$ offset to the south, corresponds to the southernmost segment attributed to the Discovery anomaly. MORB samples from this segment have homogeneous isotopic compositions that differ strongly from those from the surrounding segments (Figs. 3 and 4). Even if the most extreme isotopic ratios have been measured in MORB from other ridge segments, the Southern Discovery segment displays the most radiogenic average value for ${ }^{187} \mathrm{Os} /{ }^{188} \mathrm{Os}(0.1615 \pm 0.0016)$. Despite their high ${ }^{187} \mathrm{Os} /{ }^{188}$ Os ratios, these MORB have relatively high Os contents and low Re/Os ratios. The Southern Discovery segment has also the highest average values of ${ }^{87} \mathrm{Sr} /{ }^{86} \mathrm{Sr}(0.7048 \pm 0.0004), \Delta 8 / 4$ $(94 \pm 0.7)$ and the lowest average value for ${ }^{206} \mathrm{~Pb} /{ }^{204} \mathrm{~Pb}(17.84 \pm 0.06)$. Such isotope values, as well as the extreme trace element ratios measured in these samples [41], are similar to those of MORB and OIB from the Indian Ocean that led to the definition of the so-called DUPAL anomaly $[9,10] .{ }^{206} \mathrm{~Pb} /{ }^{204} \mathrm{~Pb}$ and ${ }^{87} \mathrm{Sr} /{ }^{86} \mathrm{Sr}$ ratios of MORB from the $48.5^{\circ}-49^{\circ} \mathrm{S}$ segment are significantly higher than the extreme Indian MORB $\left(39^{\circ}-41^{\circ} \mathrm{E}\right.$ SWIR) but are very similar to the Indian OIB. This observation suggests a significant contribution of the Discovery plume. Douglass et al. [8] have also shown that South Atlantic mantle plumes (Discovery, Tristan and Gough plumes) have peculiar isotopic signatures implying the involvement of a LOMU mantle component. This component seems thus to dominate the MORB signature of the $48.5^{\circ}-49^{\circ} \mathrm{S}$ segment that strongly contrasts with the Central Discovery segment thought to represent the plume signature. 

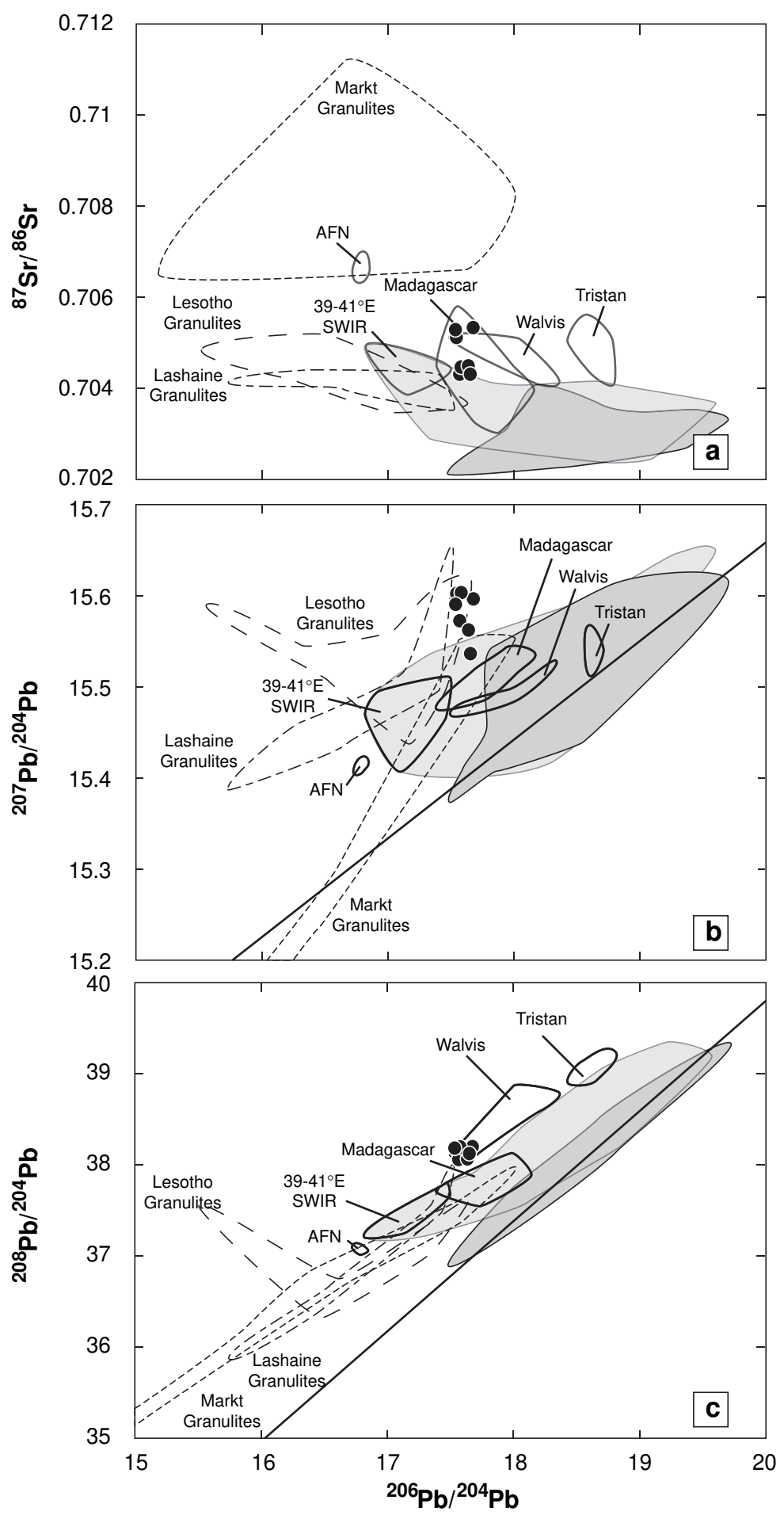
The involvement of sub-continental lithospheric mantle has been proposed to account for the LOMU component present in the Atlantic mantle $[8,13,41,44]$. As xenoliths from ancient sub-continental lithospheric mantle have specific unradiogenic (i.e., lower than primitive mantle value) Os isotope ratios (see [31] and references therein), recycling of such material in the source of MORB should impart unradiogenic Os isotope compositions on erupted basalts, relative to the 'surrounding ridge segment. Nevertheless, MORB from the $48.5^{\circ}-49^{\circ} \mathrm{S}$ segment display radiogenic ${ }^{187} \mathrm{Os} /{ }^{188} \mathrm{Os}$ ratios, which precludes sub-continental lithospheric mantle as the LOMU component and rather supports the presence of recycled crustal material in the MORB source. The high ${ }^{4} \mathrm{He} /{ }^{3} \mathrm{He}$ ratios measured in these MORB (mean: 110,000 $\pm 11,200$ ) are significantly more radiogenic than the mean MORB value $(88,000 \pm 5000$ [57]), which can also be attributed to crustal material recycling [40].

Two distinct processes can be involved in the recycling of continental material in the depleted upper mantle: subduction of sediments or crustal delamination. Sediment-related enrichment processes have already been proposed to explain the trace element and isotopic variation of the N-MORB analyzed in this study, which strongly differs from the DUPALtype E-MORB from the $48.5^{\circ}-49^{\circ} \mathrm{S}$ segment. Moreover, the radiogenic Os isotopic ratios measured in MORB from the Southern Discovery segment are consistent with Indian MORB isotopic compositions which are interpreted to reflect the recycling of lower continental crust [15]. Lower continental crust display high ${ }^{187} \mathrm{Os} /{ }^{188} \mathrm{Os}$ ratios $[58,59]$ and, on the basis of density and buoyancy criteria, is a favored part of the continental lithosphere for delamination [60]. Recently, it has been shown that high temperatures are required for dense mafic lower continental crust to sink in the mantle and that delamination may be restricted to arcs or extension areas in continental regions [61]. The location of the DUPAL anomaly, centered on the Indian Ocean close to South Africa, corresponds thus to a favored emplacement for delamination of continental material since it has encountered alternative subduction, collision and continental break-up. Douglass et al. [8] have noted that DUPAL-type basalts from the Southern Mid-Atlantic Ridge define isotopic trends toward fields of the Smoky Butte and Western Australian Lamproites and the Group 2 Kimberlites. South African's lower continental crust, as typified by the Lesotho, Lashaine and Markt granulites [62-64], also display $\mathrm{Pb}, \mathrm{Sr}, \mathrm{Nd}$ compositions consistent with these trends (Fig. 10).

\section{Conclusion and summary}

The ${ }^{187} \mathrm{Os} /{ }^{188} \mathrm{Os}$ ratios measured on MORB glasses show significant variations along the Southern Mid-Atlantic ridge $\left(40^{\circ}-50^{\circ} \mathrm{S}\right)$. Even when grouping the samples by latitudinal, trace element and isotopic criteria, the Os-Sr-Nd-Pb-Hf isotopic data present a significant dispersion that is attributed to the numerous mantle components involved and to the different processes affecting the MORB source. The Os isotopic compositions of N-MORB can be related to the contamination of the asthenospheric mantle by subduction-related melts and to the presence of radiogenic interstitial sulphides. Variations in the nature of the metasomatitic agent induce an apparent decoupling between the Os isotopic ratios, controlled by the amount of mantle melt, and the other isotopic systems, controlled by the sedimentrelated component.

The MORB ${ }^{187} \mathrm{Os} /{ }^{188}$ Os ratios appears to be very sensitive to the vicinity of the Discovery mantle plume: the latitudinal variation of ${ }^{187} \mathrm{Os} /{ }^{188} \mathrm{Os}$ ratios along the $47.35^{\circ}-48.5^{\circ} \mathrm{S}$ segment confirms the migration of Discovery plume material southward of the Agulhas FZ and the maximum interaction just South of the fracture zone.

Most importantly, MORB glasses from the $48.5^{\circ}-$ $49.2^{\circ} \mathrm{S}$ segment enable us to add constraints on the

Fig. 10. ${ }^{87} \mathrm{Sr} /{ }^{86} \mathrm{Sr}(\mathrm{a}),{ }^{208} \mathrm{~Pb} /{ }^{204} \mathrm{~Pb}$ (b) and ${ }^{207} \mathrm{~Pb} /{ }^{204} \mathrm{~Pb}$ (c) vs. ${ }^{206} \mathrm{~Pb} /{ }^{204} \mathrm{~Pb}$ diagrams for the 'low $\mu$-type' MORB from $48.5-49.2^{\circ} \mathrm{S}$ segment (black circles) and, reported as fields, other 'low $\mu$-type' oceanic basalts (Tristan [67,68], Walvis ridge [69], Madagascar [70], Afanasy-Nikitin [71], and the 39-41 E segment of the SWIR (data from the GEOROC database, http://georoc.mpch-mainz.gwdg.de/ and from PetDB, http:// petdb.ldeo.columbia.edu/petdb/) and South African lower continental crust xenoliths from Lashaine, Lesotho and Markt groups [62-64]. Grey fields are for Indian MORB (grey) and Atlantic MORB (dark grey). MORB dataset is taken from Lamont database. Recycling of South African lower continental crust in the South Atlantic and Indian upper mantle may explain the observed isotopic variations. 
nature of the LOMU component. The homogeneous radiogenic ${ }^{187} \mathrm{Os} /{ }^{188} \mathrm{Os}$ compositions of these samples could be accounted for by involving fragments of the lower continental crust delaminated during the Gondwana break-up. This result is in agreement with the previous Os studies of Indian MORB with DUPAL signature $[15,24]$, which also displayed radiogenic ${ }^{187} \mathrm{Os} /{ }^{188}$ Os ratios. Nevertheless, it is difficult to precisely estimate the composition of the LOMU component only on the basis of the $48.5^{\circ}$ $49.2^{\circ} \mathrm{S}$ segment MORB samples since their compositions are very similar to Indian OIB and suggest a significant additional contribution of plume material in their source.

\section{Acknowledgements}

Samples were collected during cruise EW9309 of the R/V Maurice Ewing. This work was supported by NSF grant OCE-9906799 to J-.G. Schilling. S.E. thanks A Bezos, R. Doucelance, C.H. Langmuir and S. Parman for helpful and constructive discussions and comments on the manuscript. Reviews from R. Carlson and S. Shirey helped to improve the manuscript quality. This is IPGP contribution 2070.

\section{References}

[1] M. Tatsumoto, C.E. Hedge, A.E. Engel, Potassium, rubidium, strontium, thorium, uranium and the ratio of strontium 87 to strontium 86 in oceanic tholeiitic basalt, Science 150 (1965) $886-888$.

[2] M. Tatsumoto, Genetic relations of oceanic basalts as indicated by lead isotopes, Science 153 (1966) 1094-1101.

[3] S.R. Hart, K-Rb, Cs-Sr and Ba contents and $\mathrm{Sr}$ isotope ratios of ocean floor basalts, Philos. Trans. R. Soc. Lond. 268 (1971) $573-587$.

[4] B. Dupré, C.J. Allègre, Pb-Sr-Nd isotopic correlation and the chemistry of the North Atlantic mantle, Nature 286 (1980) $17-22$.

[5] R.S. Cohen, N.M. Evensen, P.J. Hamilton, U-Pb, Sm-Nd and $\mathrm{Rb}$-Sr systematics of mid-ocean ridge basalts glasses, Nature 283 (1980) 149-153.

[6] J.G. Schilling, Iceland mantle plume: geochemical study of the Reykjanes Ridge, Nature 242 (1973).

[7] J.J. Mahoney, J.H. Natland, W.M. White, R. Poreda, S.H. Bloomer, R.L. Fishe, A.N. Baxter, Isotopic and geochemical provinces of the Western Indian Ocean spreading centers, J. Geophys. Res. 94 (1989) 4033-4052.
[8] J. Douglass, J.-G. Schilling, D. Fontignie, Plume-ridge interactions of the Discovery and Shona mantle plumes with the southern Mid-Atlantic Ridge $\left(40^{\circ}-55^{\circ} \mathrm{S}\right)$, J. Geophys. Res. 104 (1999) 2941-2962.

[9] B. Dupré, C.J. Allègre, $\mathrm{Pb}-\mathrm{Sr}$ isotope variation in Indian Ocean basalts and mixing phenomena, Nature 303 (1983) $142-146$.

[10] S.R. Hart, A large-scale isotope anomaly in the southern hemisphere mantle, Nature 309 (1984) 753-757.

[11] A. Michard, R. Montigny, R. Schlich, Geochemistry of the mantle beneath the Rodriguez Triple Junction and the SouthEast Indian Ridge, Earth Planet. Sci. Lett. 78 (1986) 104-114.

[12] M. Rehkämper, A.W. Hofmann, Recycled ocean crust and sediment in Indian Ocean MORB, Earth Planet. Sci. Lett. 147 (1997) 93-106.

[13] C.J. Hawkesworth, M.S.M. Mantovani, P.N. Taylor, Z. Palacz, Evidence from the Parana of south Brazil for a continental contribution to Dupal basalts, Nature 322 (1986) 356-359.

[14] J.J. Mahoney, A.P. LeRoex, Z. Peng, R.L. Fisher, J.H. Natland, Southwestern limits of Indian Ocean ridge mantle and the origin of low ${ }^{206} \mathrm{~Pb} /{ }^{204} \mathrm{~Pb}$ mid-ocean ridge basalt: isotope systematics of the central Southwest Indian Ridge $\left(17^{\circ}-50^{\circ} \mathrm{E}\right)$, J. Geophys. Res. 97 (1992) 19771-19790.

[15] S. Escrig, F. Capmas, B. Dupré, C.J. Allègre, Osmium isotopic constraints on the nature of the DUPAL anomaly from Indian mid-ocean-ridge basalts, Nature 431 (2004) 59-63.

[16] C.J. Allègre, D.L. Turcotte, Implications of a two-component marble-cake mantle, Nature 323 (1986) 123-127.

[17] M.I. Smoliar, R.J. Walker, J.W. Morgan, Re-Os ages of group IIA, IIIA, IVA and IVB iron meteorites, Science 271 (1996) 1099-1102.

[18] E.H. Hauri, S.R. Hart, Re-Os isotope systematics of HIMU and EMII oceanic island basalts from the south Pacific Ocean, Earth Planet. Sci. Lett. 114 (1993) 353-371.

[19] L. Reisberg, A. Zindler, F. Marcantonio, W. White, D. Wyman, B. Weaver, Os isotope systematics in ocean island basalts, Earth Planet. Sci. Lett. 120 (1993) 149-167.

[20] F. Marcantonio, A. Zindler, T. Elliot, H. Staudigel, Os isotope systematics of La Palma, Canary Islands: evidence for recycled crust in the mantle source of HIMU ocean islands, Earth Planet. Sci. Lett. 133 (1995) 397-410.

[21] M. Roy-Barman, C.J. Allègre, ${ }^{187} \mathrm{Os} /{ }^{186} \mathrm{Os}$ in oceanic island basalt: tracing oceanic crust recycling in the mantle, Earth Planet. Sci. Lett. 129 (1995) 145-161.

[22] P. Schiano, K.W. Burton, B. Dupré, J.-L. Birck, G. Guille, C.J. Allègre, Correlated Os-Pb-Nd-Sr isotopes in the Austral-Cook chain basalts: the nature of mantle components in plume sources, Earth Planet. Sci. Lett. 186 (2001) 353-371.

[23] M. Roy-Barman, C.J. Allègre, ${ }^{187} \mathrm{Os} /{ }^{186} \mathrm{Os}$ ratios in midocean ridge basalts and abyssal peridotites, Geochim. Cosmochim. Acta 58 (1994) 5043-5054.

[24] P. Schiano, J.L. Birck, C.J. Allègre, Osmium-strontiumneodymium-lead isotopic covariations in mid-ocean ridge basalt glasses and heterogeneity of the upper mantle, Earth Planet. Sci. Lett. 150 (1997) 363-379.

[25] A. Gannoun, K.W. Burton, L.E. Thomas, I.J. Parkinson, P.W. Van Calsteren, P. Schiano, Osmium isotope heterogeneity in 
the constituent phases of mid-ocean ridge basalts, Science 303 (2004) $70-72$.

[26] C.E. Martin, Osmium isotopic characteristics of mantle-derived rocks, Geochim. Cosmochim. Acta 55 (1991) 1421-1434.

[27] J.E. Snow, L. Reisberg, Os isotopic systematics of the MORB mantle: results from altered abyssal peridotites, Earth Planet. Sci. Lett. 133 (1995) 411-421.

[28] L. Reisberg, J.-L. Lorand, Longevity of subcontinental mantle lithosphere from osmium isotope systematics in orogenic peridotite massifs, Nature 376 (1995) 159-162.

[29] A.D. Brandon, J.E. Snow, R.J. Walker, J.W. Morgan, T.D. Mock, ${ }^{190} \mathrm{Pt}-{ }^{186} \mathrm{Os}$ and ${ }^{187} \mathrm{Re}-{ }^{187} \mathrm{Os}$ systematics of abyssal peridotites, Earth Planet. Sci. Lett. 177 (2000) 319-335.

[30] T. Meisel, R.J. Walker, J.W. Morgan, The osmium isotopic composition of the Earth's primitive upper mantle, Nature 383 (1996) 517-520.

[31] S.B. Shirey, R.J. Walker, The Re-Os isotope system in cosmochemistry and high-temperature geochemistry, Annu. Rev. Earth Planet. Sci. 26 (1998) 423-500.

[32] E.H. Hauri, Osmium isotopes and mantle convection, Philos. Trans. R. Soc. Lond. 360 (2002) 2371-2382.

[33] K.W. Burton, P. Schiano, J.-L. Birck, C.J. Allègre, Osmium isotope disequilibrium between mantle minerals in a spinellherzolite, Earth Planet. Sci. Lett. 172 (1999) 311-322.

[34] A. Luguet, O. Alard, J.-L. Lorand, N.J. Pearson, C. Ryan, S.Y. O'Reilly, Laser-ablation microprobe (LAM)-ICPMS unravels the highly siderophile element geochemistry of the oceanic mantle, Earth Planet. Sci. Lett. 189 (2001) 285-294.

[35] O. Alard, W.L. Griffin, N.J. Pearson, J.-L. Lorand, S.Y. O'Reilly, New insights into the Re-Os systematics of subcontinental lithospheric mantle from in situ analysis of sulphides, Earth Planet. Sci. Lett. 203 (2002) 651-663.

[36] O. Alard, A. Luguet, J.P. Lorand, N.J. Pearson, W.L. Griffin, S.Y. O'Reilly, Os isotopic systematic of magmatic sulfides in abyssal peridotites, Geochim. Cosmochim. Acta 68 (2004) 689.

[37] A.P. Le Roex, H.J.B. Dick, L. Gulen, A.M. Reid, A.J. Erlank, Local and regional heterogeneity in MORB from the MidAtlantic Ridge between $54.5^{\circ} \mathrm{S}$ and $51^{\circ} \mathrm{S}$ : evidence for geochemical enrichment, Geochim. Cosmochim. Acta 51 (1987) $541-555$.

[38] J. Douglass, J.-G. Schilling, R.H. Kingsley, C. Small, Influence of the Discovery and Shona mantle plumes on the southern Mid-Atlantic Ridge: rare Earth evidence, Geophys. Res. Lett. 22 (1995) 2893-2896.

[39] M. Moreira, T. Staudacher, P. Sarda, J.G. Schilling, C.J. Allègre, A primitive plume neon component in MORB: the shona ridge anomaly, South Atlantic, Earth Planet. Sci. Lett. 133 (1995) 367-377.

[40] P. Sarda, M. Moreira, T. Staudacher, J.-G. Schilling, C.J. Allègre, Rare gas systematics on the southernmost MidAtlantic Ridge: constraints on the lower mantle and the Dupal source, J. Geophys. Res. 105 (2000) 5973-5996.

[41] P.J. Le Roux, A.P. Le Roex, J.-G. Schilling, N. Shimizu, W.W. Perkins, N.J.G. Pearce, Mantle heterogeneity beneath the southern Mid-Atlantic Ridge: trace element evidence for con- tamination of ambient asthenospheric mantle, Earth Planet. Sci. Lett. 203 (2002) 479-498.

[42] M. Andres, J. Blicher-Toft, J.-G. Schilling, Hafnium isotopes in basalts from the southern Mid-Atlantic Ridge from $40^{\circ} \mathrm{S}$ to $55^{\circ} \mathrm{S}$ : discovery and Shona plume-ridge interactions and the role of recycled sediments, Geochem. Geophys. Geosyst. 3 (2002).

[43] E.M. Klein, C.H. Langmuir, Global correlations of ocean ridge basalt chemistry with axial depth and crustal thickness, J. Geophys. Res. 92 (1987) 8089-8115.

[44] S.B. Shirey, J.F. Bender, C.H. Langmuir, Three-component isotopic heterogeneity near the Oceanographer Transform, Mid-Atlantic Ridge, Nature 325 (1987) 217-223.

[45] J.-L. Birck, M. Roy-Barman, F. Capmas, Re-Os isotopic measurements at the femtomole level in natural samples, Geostand. Newsl. 20 (1997) 19-27.

[46] K.W. Burton, A. Gannoun, J.-L. Birck, C.J. Allègre, P. Schiano, R. Clocchiatti, O. Alard, The compatibility of rhenium and osmium in natural olivine and their behaviour during mantle melting and basalt genesis, Earth Planet. Sci. Lett. 198 (2002) 63-76.

[47] S.R. Hart, G.E. Ravizza, Os partitioning between phases in lherzolite and basalt, in: A. Basu, S.R. Hart (Eds.), Earth Processes: Reading the Isotopic Code, Am. Geophys. Union, 1996, pp. $123-134$.

[48] B. Peucker-Ehrenbrink, W. Bach, S.R. Hart, J.S. Blusztajn, T. Abbruzzese, Rhenium-osmium isotope ssystematics and platinum group element concentrations in oceanic crust from DSDP/ODP sites 504 and 417/418, Geochem. Geophys. Geosyst. 4 (2003).

[49] E.H. Hauri, S.R. Hart, Rhenium abundances and systematics in oceanic basalts, Chem. Geol. 139 (1997) 185-205.

[50] W. Sun, V.C. Bennet, S.M. Eggins, R.J. Arculus, M.R. Perfit, Rhenium systematics in submarine MORB and back-arc basin glasses: laser ablation ICP-MS results, Chem. Geol. 196 (2003) 259-281.

[51] C.J. Allègre, B. Hamelin, A. Provost, B. Dupré, Topology in isotopic multispace and origin of mantle chemical heterogeneities, Earth Planet. Sci. Lett. 81 (1986/87) 319-337.

[52] M. Roy-Barman, G.J. Wasserburg, D.A. Papanastassiou, M. Chaussidon, Osmium isotopic composition and Re-Os concentrations in sulfide globules from basaltic glasses, Earth Planet. Sci. Lett. 154 (1998) 331-347.

[53] S. Levasseur, J.-L. Birck, C.J. Allègre, Direct measurement of femtomoles of osmium and the ${ }^{187} \mathrm{Os} /{ }^{186} \mathrm{Os}$ ratio in seawater, Science 282 (1998) 272-274.

[54] C. DeMets, R. Gordon, D. Argus, S. Stein, Current plate motions, Geophys. J. Int. 101 (1990) 425-478.

[55] M. Rehkämper, A.N. Halliday, J.G. Fitton, D.-C. Lee, M. Wieneke, N.T. Arndt, Ir, Ru, Pt, and Pd in basalts and komatiites: new constraints for the geochemical behavior of the platinum-group elements in the mantle, Geochim. Cosmochim. Acta 63 (1999) 3915-3934.

[56] M.M. Hirschmann, E.M. Stolper, A possible role for garnet pyroxenite in the origin of the "garnet signature" in MORB, Contrib. Mineral. Petrol. 124 (1996) 185-208. 
[57] C.J. Allègre, M. Moreira, T. Staudacher, ${ }^{4} \mathrm{He} /{ }^{3} \mathrm{He}$ dispersion and mantle convection, Geophys. Res. Lett. 22 (1995) 2325-2328.

[58] R.W. Esperança, R.W. Carlson, S.B. Shirey, D. Smith, Dating crust-mantle separation: Re-Os isotopic study of mafic xenoliths from central Arizona, Geology 25 (1997) 651-654.

[59] A.E. Saal, R.L. Rudnick, G.E. Ravizza, S.R. Hart, Re-Os isotope evidence for the composition, formation and age of the lower continental crust, Nature 393 (1998) 58-61.

[60] R.W. Kay, S. Mahlburg Kay, Delamination and delamination magmatism, Tectonophysics 219 (1993) 177-189.

[61] M. Jull, P.B. Kelemen, On the condition for lower crust convective instability, J. Geophys. Res. 106 (2001) 6423-6446.

[62] R.S. Cohen, R.K. O’Nions, J.B. Dawson, Isotope geochemistry of xenoliths from East Africa: implications for development of mantle reservoirs and their interaction, Earth Planet. Sci. Lett. 68 (1984) 209-220.

[63] N.W. Rogers, C.J. Hawkesworth, Proterozoic age and cumulate origin for granulite xenoliths, Lesotho, Nature 299 (1982) 409-413.

[64] Y.-M. Huang, P.W. Van Calsteren, C.J. Hawkesworth, The evolution of the lithosphere in southern Africa: a perspective on the basic granulite xenoliths from kimberlites in South Africa, Geochim. Cosmochim. Acta 59 (1995) 4905-4920.
[65] C. Chauvel, A.W. Hofmann, P. Vidal, HIMU-EM: the French Polynesian connection, Earth Planet. Sci. Lett. 110 (1992) $99-119$.

[66] J.-G. Schilling, B.B. Hanan, B. McCully, R.H. Kingsley, D. Fontignie, Influence of the Sierra Leone mantle plume on the equatorial Mid-Atlantic Ridge; a $\mathrm{Nd}-\mathrm{Sr}-\mathrm{Pb}$ isotopic study, J. Geophys. Res. 99 (1994) 12005-12028.

[67] A.P. Le Roex, R. Cliff, B. Adair, Tristan da Cunha, south Atlantic: geochemistry and petrogenesis of a basanitephonolite lava series, J. Petrol. 31 (1990) 779-812.

[68] R.A. Cliff, P.E. Baker, N.J. Mateer, Geochemistry of inaccessible island volcanics, Chem. Geol. 92 (1991) 251-260.

[69] S.H. Richardson, A.J. Erlank, A.R. Duncan, D.L. Reid, Correlated $\mathrm{Nd}, \mathrm{Sr}$ and $\mathrm{Pb}$ isotope variation in walvis ridge basalts and implications for evolution of their mantle source, Earth Planet. Sci. Lett. 59 (1982) 327-352.

[70] J.J. Mahoney, C. Nicollet, C. Dupuy, Madagascar basalts: tracking oceanic and continental sources, Earth Planet. Sci. Lett. 104 (1991) 350-363.

[71] J.J. Mahoney, W.M. White, B.G.J. Upton, C.R. Neal, R.A. Scrutton, Beyond EM-1: lavas from Afanasy-Nikitin Rise and the Crozet Archipelago, Indian Ocean, Geology 24 (1996) 615-618. 